\title{
KOMPLEX ZANIKLÝCH HŘBITOVŮ V PRAZE-KARLÍNĚ
}

\author{
PAVEL KACL - ERIKA PRŮCHOVÁ
}

\begin{abstract}
Abstrakt: Ve formě předběžné zprávy jsou v př́spěvku shrnuty poznatky výzkumu vojenského a evangelických hřbitovi̊ z 18. a 19. století, na nichž bylo odkryto 1019 hrobů jednočetných $i$ vícečetných (včetně masových) v různých stupních zachovalosti. V průběhu výzkumu byly dokumentovány i stavební konstrukce souvisejícís hřbitovy i se stavebnimi aktivitami v průběhu 20. století.
\end{abstract}

Kličová slova: novověk - pohřební ritus - vojenský hřbitov - evangelický hřbitov - hřbitov invalidi̊.

\section{A Complex of Defunct Cemeteries in Prague-Karlín}

Abstract: This paper sums up, in the form of a preliminary report, results of research into a military cemetery and Evangelical cemeteries from the 18th and 19th centuries in which 1,019 graves were unearthed, both of individuals and groups (including mass graves) in a varying degree of preservation. The research also involved the documentation of constructions connected with cemeteries and with building activities in the 20th century.

Key words: modern age - funeral rite - military cemetery - Evangelical cemetery - cemetery for the disabled.

Archeologický výzkum parcel č. 663/1, 664/1,665/1,665/2 a 665/3, dotčených výstavbou velké administrativní budovy pod názvem AFI Karlín Business Centre, mezi Korybutovou a Pernerovou ulicí v Praze 8 - Karlíně (obr. 1), byl zahájen zjišt'ovací sondáží v lednu 2013. Ve třech liniových výkopech byly odhaleny terény pohřebiště, zděné konstrukce a až dva metry mocné navážky (Kacl ed. 2013). Následovala terénní část předstihového výzkumu, koncipovaného od počátku jako antropologicko-archeologický projekt, která proběhla od června do listopadu stejného roku. Na základě poznatků ze zjištovacího výzkumu, rešerše historických pramenů a po konzultaci v Pražské regionální archeologické komisi byl vytipován prostor pro exkavaci reprezentativního vzorku tak, aby zahrnul části luteránského, helvetského i vojenského hřbitova. Realizovaný vzorek dosáhl asi 12 procent plochy postižené stavbou (tab. 1), kde zachytil 1019 hrobů s ostatky 1429 jedinců ( 869 jedinců na hřbitově vojenském, 85 na luteránském a 475 na helvetském). K tomu je nutno říci, že hustota hrobů nebyla v celém rozsahu stejná. Pro jižní část souboru hřbitovů byly charakteristické vlhké ulehlé hlinité a štěrkovité svahoviny, do kterých se hrobové jámy musely místy hloubit bezpochyby obtížně. Tyto sedimenty zároveň zpomalovaly rozklad pohřbených těl. Výběr byl proto cílen mj. na prostor s největší prokázanou hustotou hrobů s ohledem na zdravotní rizika a lidské možnosti výzkumu.

\begin{tabular}{|c|c|c|c|c|}
\cline { 2 - 5 } \multicolumn{1}{c|}{} & \multicolumn{3}{c|}{ rozloha $\left(\mathrm{m}^{2}\right)$} \\
\hline hřbitov & celková & zasažená & dokumentovaná & částečně dokumentovaná \\
\hline vojenský & 12155 & 3241 & 450 & 100 \\
\hline luteránský & 2508 & 1679 & 75 & 0 \\
\hline helvetský & 3870 & 2258 & 250 & 0 \\
\hline 1. důstojnický & 2070 & 0 & 0 & 0 \\
\hline 2. důstojnický & 3553 & 0 & 0 & 250 \\
\hline celkem & 24156 & 7178 & 775 & \\
\hline
\end{tabular}

Tab. 1. Rozsahy komplexu hřbitovů podle původních maximálních rozměrů (hodnoty mohou být mírně nepřesné), částí zasažených stavbou a exkavovaného vzorku. Do helvetského hřbitova je počítána i plocha rozšírení pravděpodobně z roku 1863.

Tab. 1. Umfänge des Friedhofskomplexes nach den ursprünglichen Maximalabmessungen (die Werte können leicht ungenau sein), von Bau und ausgehobener Probe betroffene Teile. Beim helvetischen Friedhof wurde auch die Erweiterungsfläche hinzugezählt, wie sie wahrscheinlich im Jahr 1863 dazukam. 


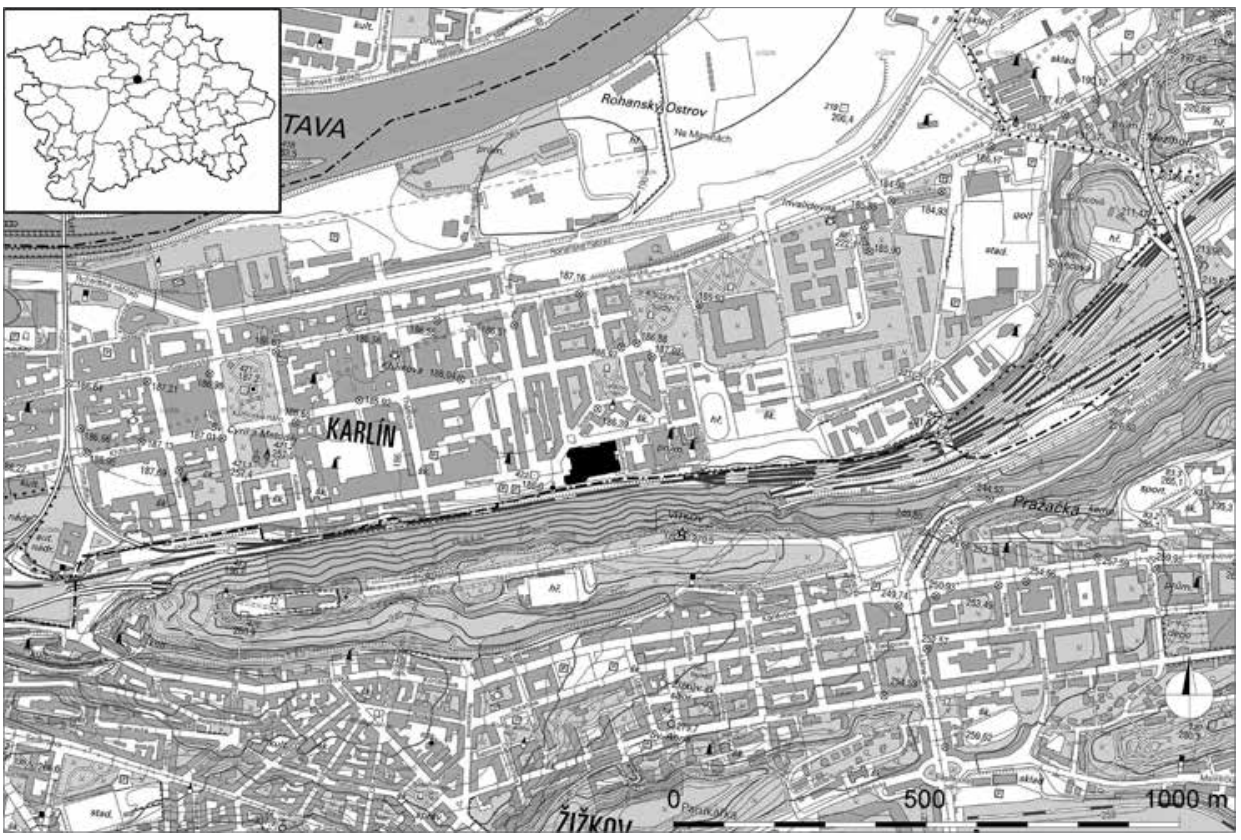

Obr. 1. Poloha výzkumu v rámci Prahy a Karlína. Podklad http://geoportal.gov.cz/web/guest/map.

Abb. 1. Lage der Grabung im Rahmen von Prag und Karolinenthal. Unterlage http://geoportal.gov.cz/web/guest/map.

Na zbytku plochy byly zdokumentovány stavební konstrukce (s výjimkou recentních betonových základů) a odkryty hrobky a zděné hrobové obruby (obr. 2). S ostatky z nezkoumané části pohřebiště se zavázal investor naložit tak, aby byly při stavebních pracích vyzvednuty a znovu uloženy. V době psaní tohoto příspěvku byla dokončována nálezová zpráva (Kacl ed. 2017).

Prostor někdejšího pohřebiště se nachází v nadmořské výšce okolo $186 \mathrm{~m} \mathrm{n}$. m. a na jižní straně se přimyká ke svahu vrchu Vítkova (Žižkova). Bezprostřední geologické podloží tvořily lehce rozpojitelné prachovité, jemně písčité a hlinité povodňové náplavy ze staršího i mladšího období kvartéru. K porušení a odstranění holocenního půdního pokryvu došlo při hloubení hrobových jam a dalších zemních zásazích. Od jihu do poloviny zkoumané plochy zasahovalo a vykliňovalo souvrství svahovin v podobě prachovitých hlín s ostrohranným křemencovým štěrkem, placičkami břidlic a úlomky prejzů nebo křemencových sutí se stř́pkovitými úlomky břidlic (Zavřel 2017).

\section{Historické shrnutí}

Počátky hřbitovů v prostoru dnešních ulic Pernerovy, Šaldovy a Korybutovy (obr. 3) sahají do 18. století, a to patrně k roku 1753. Byly zřízeny na území tehdejšího Špitálska (Špitálského pole) ve vzdálenosti necelých tř́ set metrů jihozápadně od Invalidovny, ústavu založeného z nadace hraběte Petra Strozziho (1626-1664) pro zajištění válečných invalidů a vysloužilců a vystavěného podle upravených plánů Kiliána Ignáce Dientzenhofera mezi lety 1731 a 1737. Projekt byl realizován jen v jedné devítině původního velkorysého návrhu. Prvních dvě stě ,,churavců“ včetně lékařů a dalšího personálu, kteří chod Invalidovny zajištovali, se nastěhovalo do ještě nedokončeného objektu v roce 1735. Podle úmrtních matrik byli zemřelí pochováváni na hřbitově u kostela sv. Pavla východně od Poříčské brány při brandýské silnici (Heřmánek 2015, 


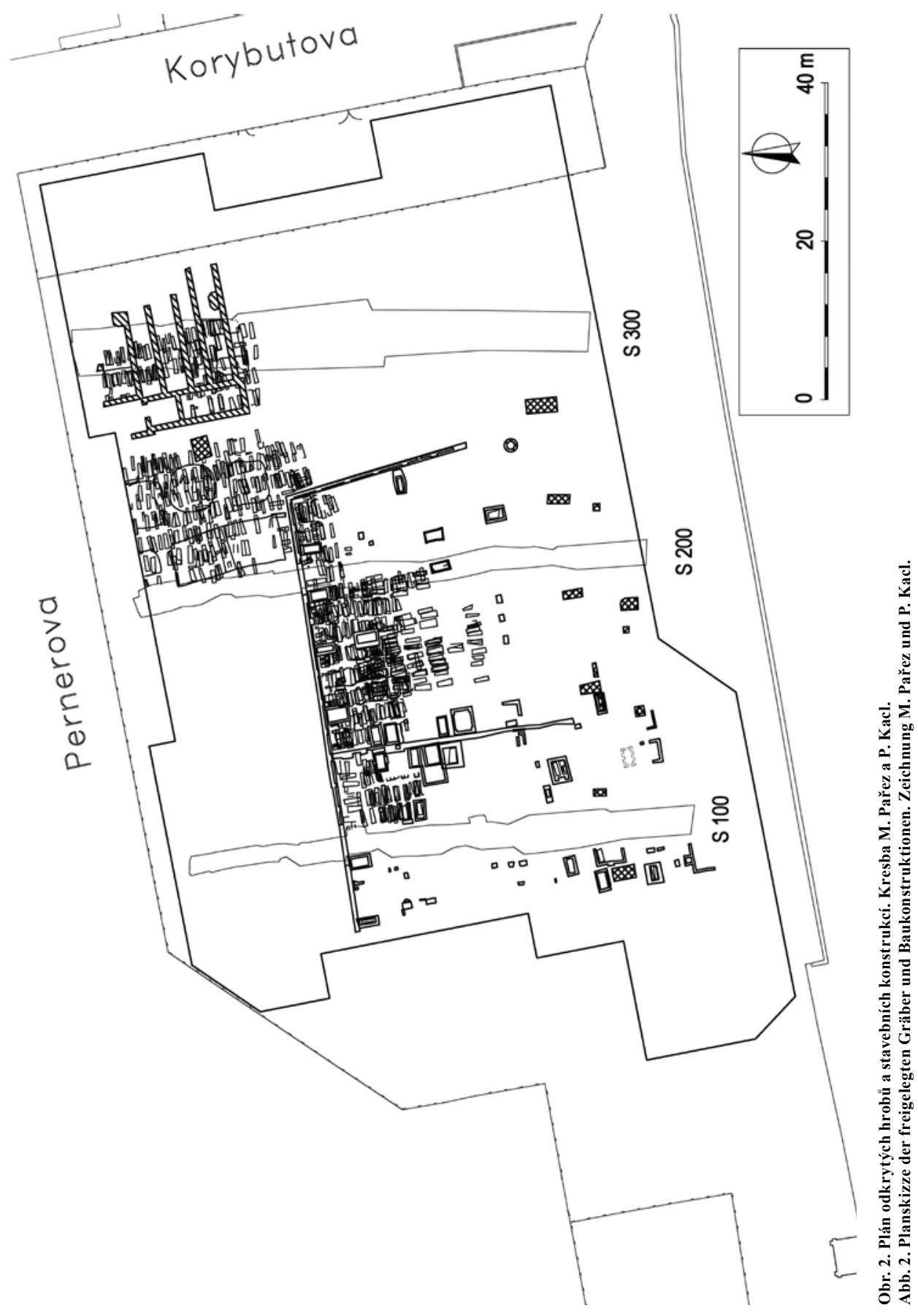




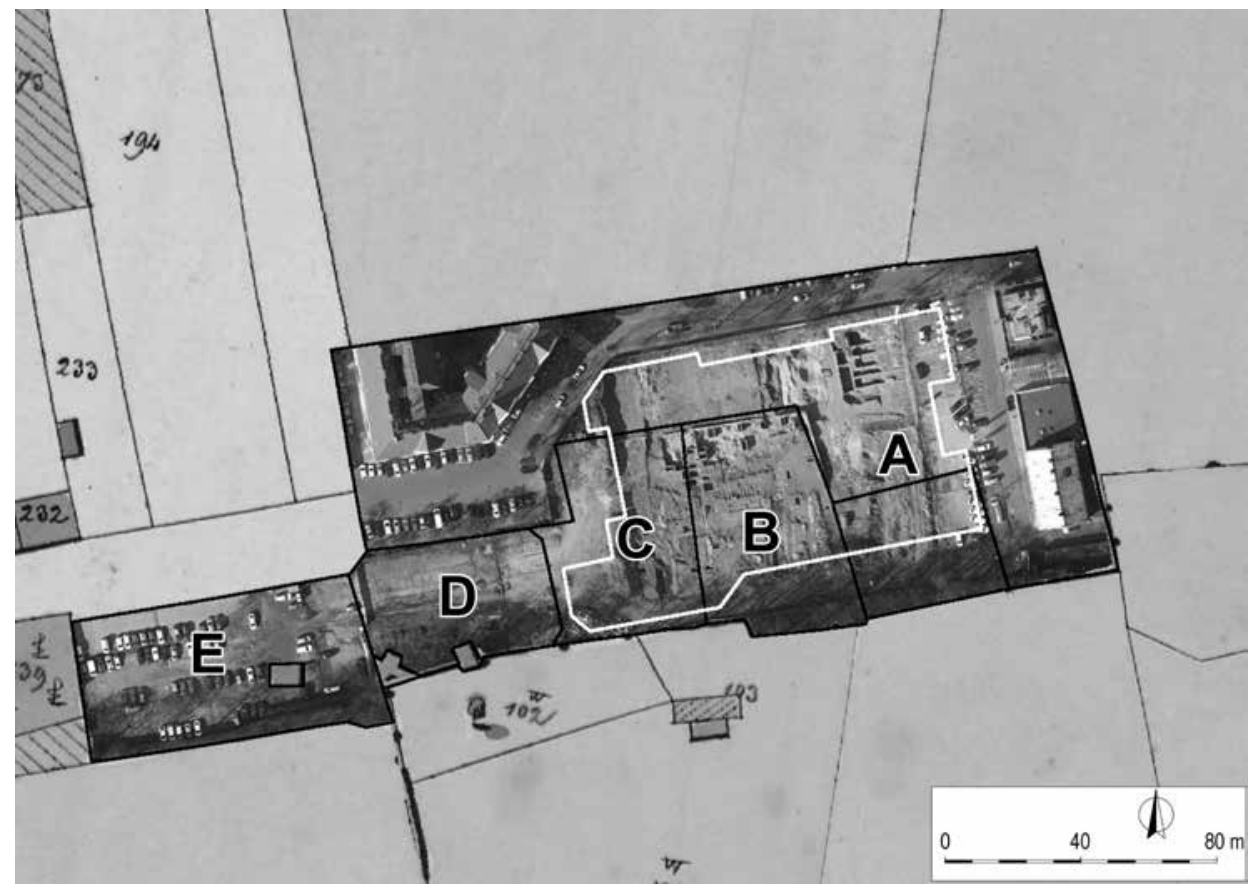

Obr. 3. Letecký snímek z počátku roku 2014 vsazený do povinných císařských otisků stabilního katastru (1840) umožňuje dobrou představu o rozsahu hřbitovního komplexu v dnešní zástavbě. Vyznačena je také plocha výzkumu. A - vojenský hřbitov pro mužstvo a invalidy, B - helvetský hřbitov, C - luteránský hřbitov, D - důstojnický hřbitov, E - důstojnický hřbitov. Podklad http://mpp.praha.eu/OrtofotoArchiv, http://archivnimapy.cuzk.cz.

Abb. 3. Luftaufnahme von Anfang 2014, eingefügt in verbindliche kaiserliche Abdrücke des stabilen Katasters (1840) gibt sie eine gute Vorstellung vom Umfang des Friedhofskomplexes in der heutigen Bebauung. Auch die Grabungsfläche wurde eingezeichnet. A - Militärischer Friedhof für Mannschaft und Invaliden, B - helvetischer Friedhof, C - lutherischer Friedhof, D - Offiziersfriedhof, E - Offiziersfriedhof. Unterlage http://mpp.praha.eu/OrtofotoArchiv, http://archivnimapy.cuzk.cz.

26, 67). Toto pohřebiště bylo císařským nařízením roku 1787 i s kostelem zrušeno (Kneidl 1923, 308; Čechura 2012, 215-216). Na počátku již zmíněného roku 1753 byla do úmrtní matriky z let 1751-1784 slavnostně vepsána zmínka o pohřbívání „na novém hřbitově domu invalidư““ (Heřmánek 2015, 67). Na konci roku 1753 pak byl c. k. pražským hospodářským ředitelstvím založen vojenský „,hřbitov s kapli a kostnici“". Pohřebiště kromě invalidů a jejich rodin začalo sloužit celé pražské vojenské posádce, mužstvu i důstojníkům (Kneidl 1923, 271; Michálková-Michálek 2008, 65, 69).

Pokud prvních osmnáct let chodu Invalidovny postačoval hřbitov při kostele sv. Pavla, vzdálený asi 1300 metrů (obr. 4), pak není překvapivý fakt, že ke zřízení vlastního (následně společného vojenského) pohřebiště došlo až roku 1753 (srov. Michálková-Michálek 2008, 66; Heřmánek 2015, 114; Pařez 2017). Hřbitovní kaplí je pozdně barokní stavba čtvercového půdorysu s okrouhlým presbytářem, jejíž interiér byl vyzdoben freskovou malbou korunovace Panny Marie a českých patronů (Kučera 2004; Michálková-Michálek 2008, 126-128).

Dalším důležitým mezníkem ve vývoji hřbitovního komplexu je rok 1784 . Tehdy k vojenskému pohřebišti přibyly hřbitovy protestantské - luteránský a helvetský. Avšak již o sedm let dřive, čtyři roky před vydáním tolerančního patentu, roku 1777 bylo norimberským kupcům povoleno zř́zení krypty pro nekatolické důstojníky a některé kupce. Krypta byla zbudována roku 1781 (Kovařík 2001, 293-294; Michálková-Michálek 2008, 68-69). Její poloha dnes není známa. 


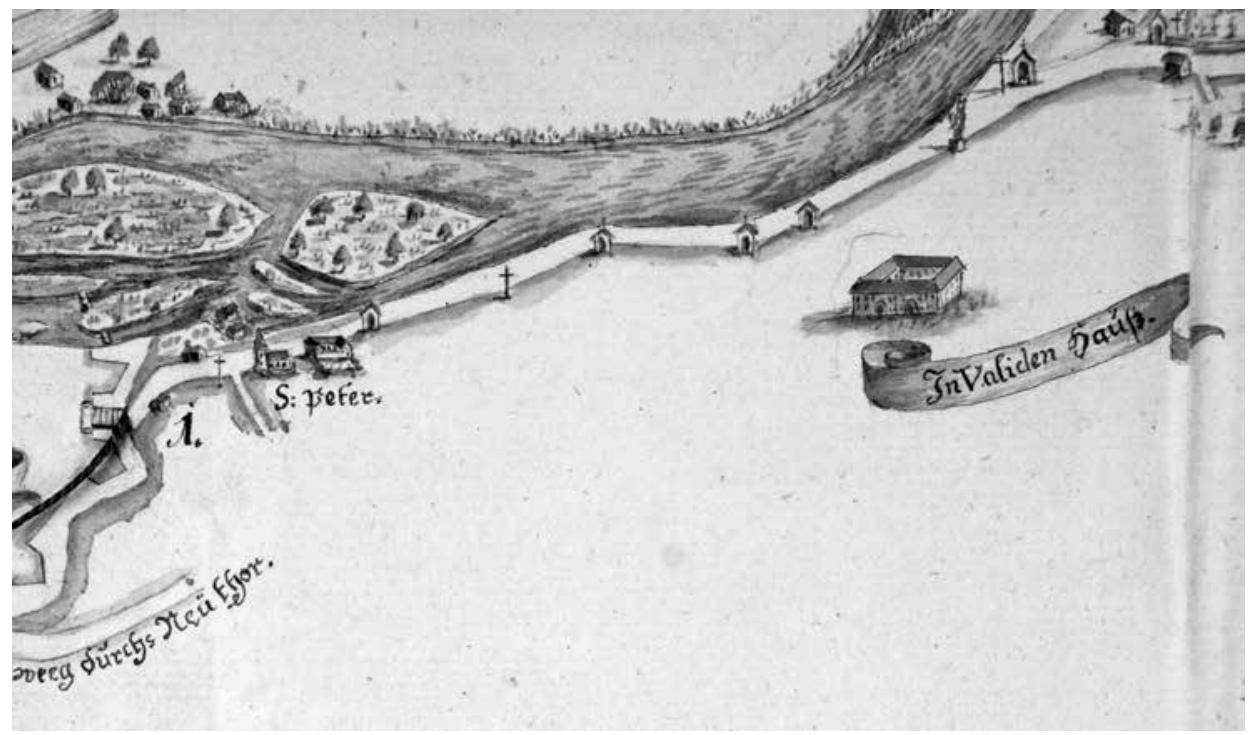

Obr. 4. Výřez z Kloseho mapy (1733) s vyobrazením Špitálska. V levé části je zachycen kostel Obrácení sv. Pavla (zde s nepřesným označením - někdy byl též uváděn jako sv. Petra a Pavla). Zdroj J. J. Clauser (viz též Pařez 1999), foto J. Pařez. Abb. 4. Ausschnitt aus einer Klose-Karte (1733) mit Darstellung der Spitalgasse. Im linken Teil wird die Kirche Bekehrung des HI. Paulus dargestellt (hier mit ungenauer Bezeichnung - manchmal wurde sie auch als Peter und Paul-Kirche angegeben). Quelle J. J. Clauser (siehe auch Pařez 1999), Foto J. Pařez.

K rozšíření vojenského hřbitova došlo v roce 1801 (o 480 čtverečných sáhů, což odpovídá $1726 \mathrm{~m}^{2}$; prostor nejstarší části a nově připojené západní parcely byl vyčleněn pro důstojníky), k rozšíření hřbitovů evangelických v roce 1863, předtím možná již v roce 1833 (Kneidl 1923, 271; Kovařík 2001, 295; Michálková-Michálek 2008, 68-69).

Po dlouholeté snaze karlínské obce o zrušení celého pohřebiště bylo oficiální a konečné stanovisko vydáno v roce 1894, čtyři roky po ničivých záplavách. K exhumacím ostatků z vojenského hřbitova se přistoupilo až na podzim roku 1904 a práce probíhaly do konce roku 1905. Podle zpráv mělo být vykopáno čtyři tisíce obyčejných vojáků a jeden tisíc důstojníků. Jejich ostatky byly následně znovu pohřbeny většinou na Olšanských hřbitovech, v některých případech i s pomníky. Po skončení exhumací byla plocha vojenského hřbitova předána městu Karlínu (Michálková-Michálek 2008, 83, 87-92, 107-125, 131-135). Některé hroby evangelíků byly rovněž přeneseny (Kovařík 2001, 295). Roku 1906 byla část nově nabytých karlínských pozemků prodána Akciové společnosti, dříve Breitfeld, Daněk a spol., později toho roku odkoupil Karlín první část evangelických hřbitovů a v roce 1911 pak zbytek. Hřbitovy byly zarovnány vrstvou navážek, ve stř̌ední a východní části na nich byla zřízena obecní pokusná a zásobní zahrada a okrajové části překryly podle regulačního plánu nové ulice. Kvůli rozššření továrny a zřízení vlečné dráhy odprodalo město Karlín v roce 1917 Akciové společnosti (od roku 1927 ČKD) pozemky obecní zahrady (Michálková-Michálek 2008, 91-92).

Továrním provozům poté sloužila značná část plochy zrušených hřbitovů po zbytek 20. století. Viditelnou připomínkou zůstávala márnice, později obydlí hrobníka a převozníka, která byla zbourána v roce 1952, a do dnešních dnů dochovaná kaple (Kučera 2004; Michálková-Michálek 2008, 83, 126-128).

Z doby existence hřbitova se zachovalo jen velmi málo ikonografických pramenů. Fotografie několika důstojnických hrobů před jejich přenesením na Olšanské hřbitovy byly 
v nedávné době publikovány (Míka 2011, obr. 224-225), stejně tak litograficky ztvárněný pohled na pohřebiště ze svahu Vítkova (obr. 5:1). Dủležité je rovněž vyobrazení na Monumentálním plánu královského hlavního města Prahy z roku 1885, jež zachycuje i detaily, jako jsou náhrobek P. J. Šafař́ḱka nebo márnice (obr. 5:2).
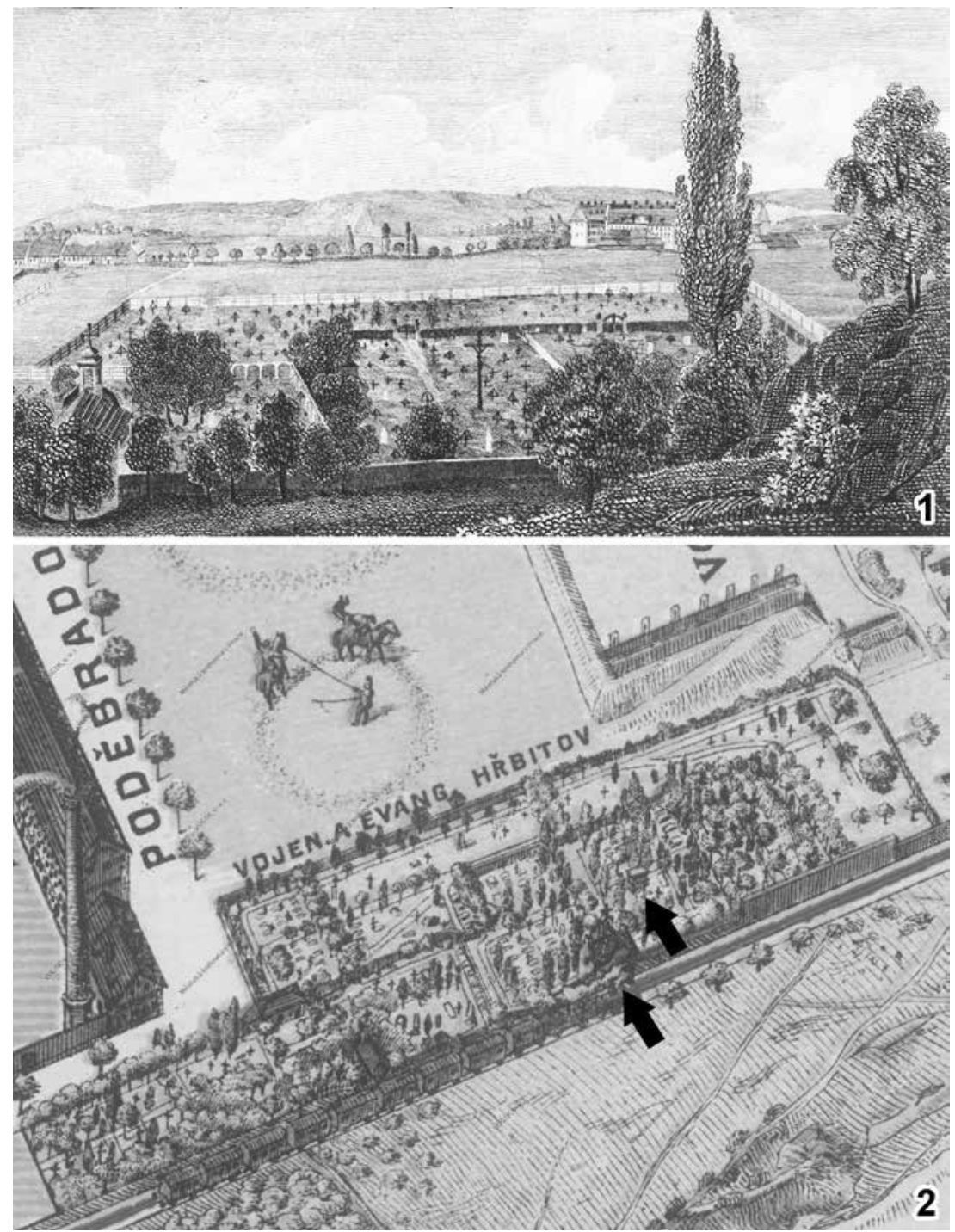

Obr. 5.1 - Pohled na hřbitovy od jihu, ze svahu Vítkova, okolo roku 1850, anonymní litografie. Podle Míka 2011. 2 - Výřez z Monumentálního plánu královského hlavního města Prahy (i s nejnovějǔí VII. částí mezi Holešovicemi a Bubny), Karlína, Král. Vinohradů, Žižkova, Bubenče, Nuslí a Smíchova, 1885, J. Brož. Šipkami jsou označeny márnice (dole) a náhrobek P. J. Šafaříka (nahoře). Zdroj http://www.chartae-antiquae. cz/ss/maps/19869.

Abb. 5. 1 - Blick auf die Friedhöfe von Süden, vom Veitsberg, um das Jahr 1850, anonyme Lithographie. Nach Míka 2011. 2 - Ausschnitt aus einem Monumentalplan der königlichen Hauptstadt Prag (auch mit dem neuesten VII. Teil zwischen Holleschowitz und Buben), Karolinenthal, Kgl. Weinberge, Veitsberg, Bubenetsch, Nussl und Smichow, 1885, J. Brož. Mit einem Pfeil gekennzeichnet wurden die Leichenhalle (unten) und der Grabstein von P. J. Šafařík (oben). Quelle http://www.chartae-antiquae.cz/cs/maps/19869. 


\section{Hroby}

S ohledem na charakter archeologického výzkumu (plocha tří zrušených hřbitovů) byla od počátku plánována přítomnost biologické antropoložky v terénní části. Spolupráce se ukázala jako velmi prŕnosná, především při rozpoznání tafonomických procesů, orientaci ve složitých nálezových situacích hromadných hrobů a předběžných odhadech demografických parametrů pohřbených jedinců. V průběhu exkavace byly dále upraveny antropologické terénní protokoly a s tím i metodika práce při dokumentaci a vyzvedávání kosterních ostatků, a to především z vícečetných hrobů (blíže Průchová-Chroustovský-Kacl, v tisku).

Hroby se nacházely v různých úrovních a nezrrídka se porušovaly. Kvůli značné míře překopaného terénu, shodných výplní hrobových jam s charakterem vrstev, do nichž byly zahloubeny, a vzájemným superpozicím nebylo obvykle možné zachytit hrobové jámy. Výjimkou byly hroby v nejnižších úrovních, kde se ve světlém písčitém podloží obrysy dobře rýsovaly. Zpravidla byly př́i plošném snižování zachyceny jako první hrany rakví a až posléze ostatky.

Téměř dvě třetiny hrobů lze charakterizovat jako výsledek jednočetných, tj. individuálních pohřbů. U většiny z nich jsme na základě artikulace kloubních spojení odhadli, že šlo o uložení do primárního dutého prostoru. Primární dutý prostor je ohraničený prostor obklopující mrtvé
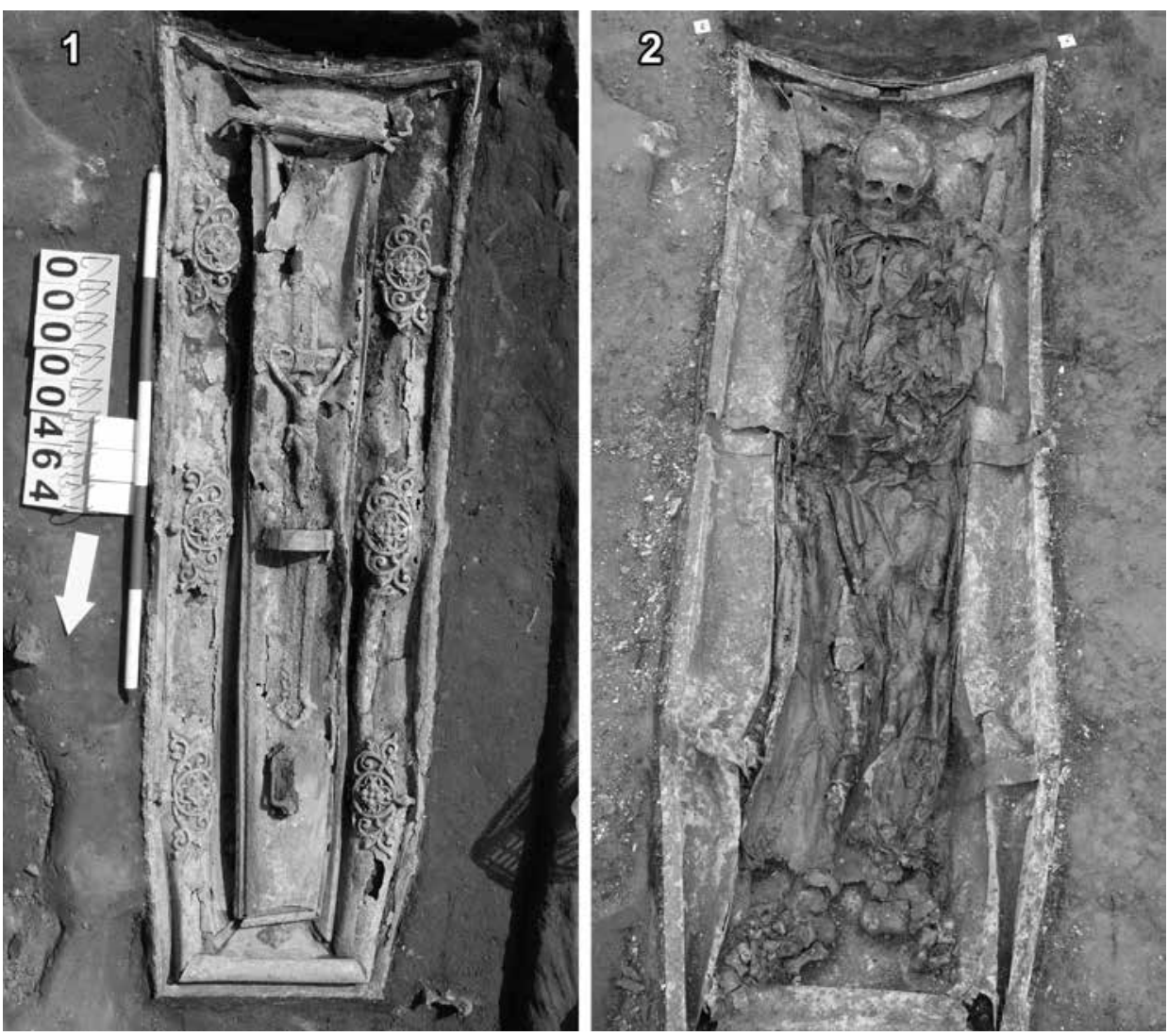

Obr. 6. Hrob 0464. 1 - víko plechové rakve s kovovým držadlem dřevěného obalu; 2 - nebožtík s pozůstatky oděvu po odstranění víka rakve. Foto $P$. Kacl.

Abb. 6. Grab 0464. 1 - Deckel eines Blechsarges mit Metallgriff der Holzverkleidung; 2 - Verstorbener mit Kleidungsüberbleibseln nach Öffnung des Sargdeckels. Foto P. Kacl. 

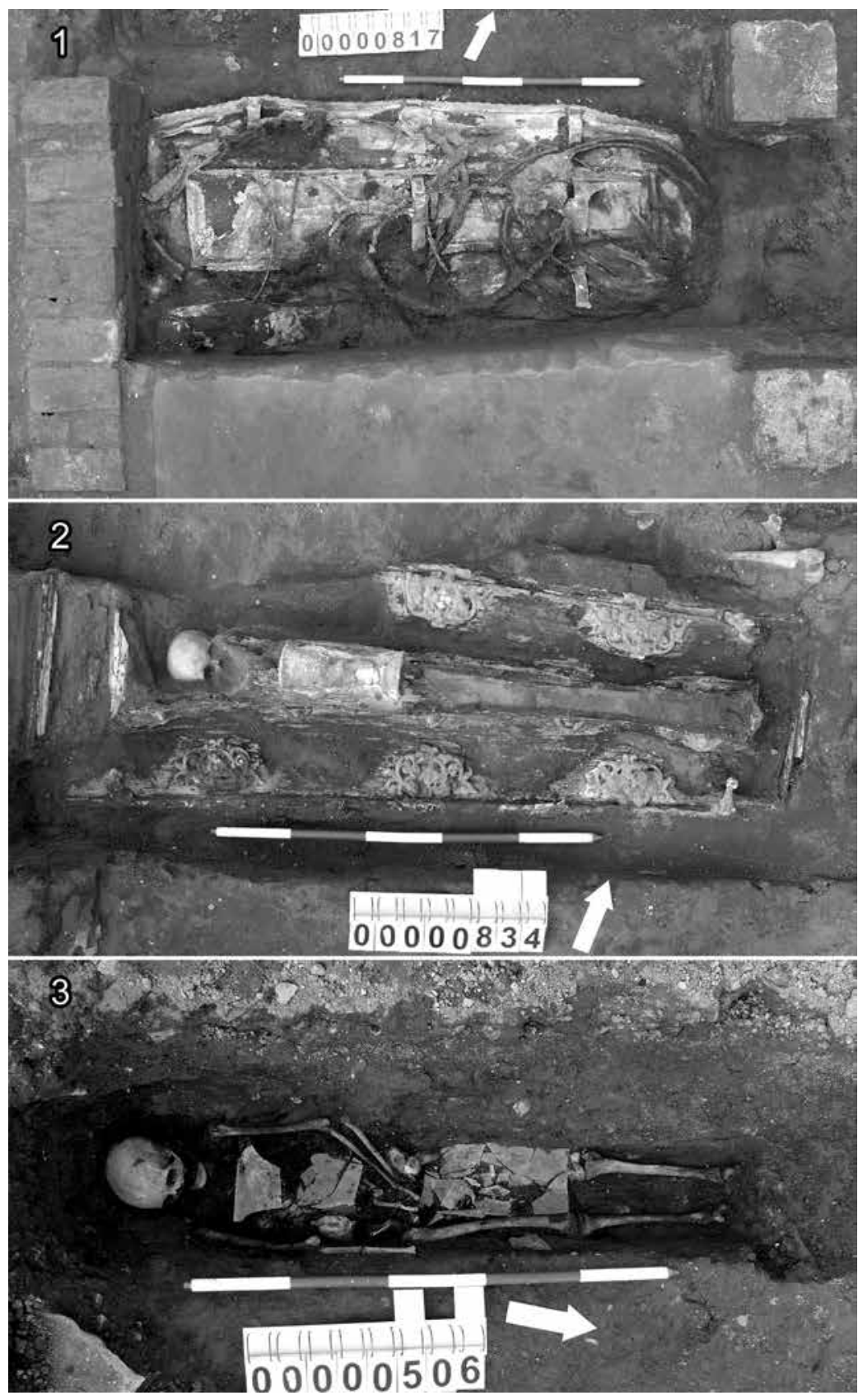

Obr. 7. 1 - hrob 0817, kovová rakev s kovovými a textilními pozůstatky věnců a konstrukcemi F3 001, F4 004, F4 005; 2 - hrob 0834, dřevěná rakev s kovovými aplikacemi včetně kalichu; 3 - hrob 0506, dřevěná rakev s tabulí skla. Foto $P$. Kacl.

Abb. 7. 1 - Grab 0817, Metallsarg mit Metall- und Textilüberresten von Kränzen und mit den Konstruktionen F3 001, F4 004, F4 005; 2 - Grab 0834, Holzsarg mit Metallapplikationen einschließlich eines Kelches; 3 - Grab 0506, Holzsarg mit Glasscheiben. Foto P. Kacl. 
tělo od počátku pohřbení. V důsledku toho dojde k posunu kostí v součinnosti působení gravitace a nerovnovážného stavu, ve kterém se nacházejí kosti (Duday et al. 1990, 34). Archeologicky byly detekovány zbytky dřevěných rakví. Odkryto bylo výzkumem deset rakví kovových, z toho osm velkých (0394, 0464 [obr. 6], 0522, 0653, 0782, 0788, 0817 [obr. 7:1], 0888) a dvě dětské $(0375,0411)$. Byly zrrejmě vyrobeny ze zinku či zinkové slitiny. Pohřby 0522 a 0888 byly uloženy do zděných hrobek (E5 001 a J11 001), hrob 0394 se vyznačoval přítomností tzv. hrobové obruby. Pouze hroby 0522, 0782, 0817 se nacházely na luteránském hřbitově, zbytek hrobů s kovovými rakvemi byl zjištěn v prostoru hřbitova helvetského.

Dvě kovové rakve $(0375,0464)$ byly do země uloženy v dřevěných truhlách, jak je to dobře vidět na případě hrobu 0464. Je možné, že některé hluboké, jednoduché dřevěné rakve beze stop po ostatcích $(0364,0452,0463,0488,0524,0573,0803)$ snad mohly být takovými schránami, z nichž později byly kovové rakve vyňaty a znovu uloženy jinde.

Také některé dřevěné rakve vykazovaly přítomnost kovových součástí - nejčastěji držadel, občas nožek (v podobě lvích tlap) či aplikací náboženské nebo ornamentální povahy. Držadla byla vyrobena ze slitiny mědi (pravděpodobně mosazi), ze železa nebo ze zinku či slitiny zinku. Jejich součástí byly i dvojice ozdobných terčíků nebo lvích maskaronů (obr. 9:1-3).

Na víkách rakví se objevovaly:

- krucifixy (ze zinku či zinkové slitiny: 0366, 0692, 0838)

- dřevěné kř́íže s plechovým korpusem (0810 [obr. 8:3], 0898)

- dřevěné kř́íže na víku rakve (0424, 0707)

- korpusy (ze zinku či zinkové slitiny: 0671, z keramiky: 0644 [obr. 8:5])

- kalichy plastické (ze zinku či zinkové slitiny: 0658, 0834 [obr. 7:2], 0863, 0905, 0915)

- kalichy z lisovaného plechu (ze slitiny mědi: 0373 [obr. 8:1], 0413, 0439, 0460, 0565, 0700)

- ornamentální výzdoba (ze zinku či zinkové slitiny: 0419, 0443, 0643, 0834 [obr. 7:2], 0905, 1038)

- ornamentální výzdoba z lisovaného plechu (ze slitiny mědi: 0374, 0416, 0442, 0480, 0491, 0507, 0538 [obr. 8:2], 0607, 0637, 0692, 0741, 0757, 0758, 0823, 0840, 0885, 0931, 0941)

Výjimečnou aplikací byla tabulka z lisovaného plechu na rakvi hrobu 0758 s letopočtem 1850 (obr. 9:4). Některé dřevěné rakve nesly i lépe či hůře dochovanou vrstvu laku. Zvláštností byl hrob $0506 \mathrm{~s}$ rozbitou tabulí tenkého skla pod zbytky rozpadlého dřevěného víka - rakev byla částečně prosklená (obr. 7:3).

Ke spojování dílů dřevěných rakví sloužily hřebíky. Ty také indikovaly původní přítomnost rakví v př́ípadě úplného rozložení dřeva.

Výjimečně byly odkryty i dřevěné rakve, do nichž bylo uloženo více těl jedinců (0716, 0771, 0999). Hroby, do nichž byli pochováni nebožtíci bez rakví, se někdy vyznačovaly přítomností vápnitých konkrecí. Pozůstatky po zasypávání těl vápnem byly identifikovány ve 21 př́padech, $\mathrm{z}$ toho pět kontextů byly jednočetné hroby a zbytek vícečetné hroby (tab. 2). Vápno netvořilo jednolitou vrstvu, ale nacházelo se spíše v kusech. Nebyly jím tak pokryty všechny kostry ve vícečetných hrobech. Na některých vápnitých kusech bylo možné pozorovat otisky rostlinného původu (trávy či slámy?). Obecně se uvádí použití vápna jako profylaktického a asanačního prostředku před šiřením nákazy a zápachu (Rigeade 2007, 101-102). Bylo používáno zejména ve zvláštních kontextech ozbrojených konfliktů a epidemií (Rigeade 2007, 102), nejčastěji bývá zmiňováno v souvislosti s morovými epidemiemi (Castex-Georges-Blanchard 2008, 9; Bianucci et al. 2009, 616-617).

Na některých rakvích ležely zbytky věnců, obvykle v podobě proutku omotaného železnými dráty, železných drátů, větviček (zřejmě zimostrázu) nebo i stuh (obr. 7:1). Větvičkami jak jehličnatých (patrně zejména túje), tak listnatých rostlin (snad zimostrázu) byly vyloženy vnitřky některých rakví. V hrobě 0888 byl na těle přítomen palmový list, v př́ípadě hrobů 0653 a 0817 ležel na rakvi. Jiný palmový list byl nalezen na podlaze prázdné hrobky F5 001. 
Celkem bylo prozkoumáno 1337 primárních pohřbů, tedy 93,6\%, v různých stupních zachovalosti. Pod pojmem primární pohřeb rozumíme pohřbení krátce po smrti na místo konečného uložení, kde proběhla celá dekompozice těla a s mrtvým nebylo dále manipulováno (např. Duday et al. 1990, 31; Duday 2005, 166). Nezř́ídka šlo pouze o pozůstatky narušených hrobů v podobě částí skeletů nebo jen o části rakví. Výjimečně, celkem ve dvanácti případech, obdržela číselná označení i druhotná uložení disartikulovaných kostí.

Vedle jednočetných jsme odkryli i vícečetné hroby, tedy hroby o intencionálním společném uložení dvou a více jedinců. Celkem jich bylo exkavováno třicet. $Z$ plochy vojenského hřbitova to znamenalo sedmnáct kontextů se 489 jedinci, $z$ helvetského hřbitova to bylo jedenáct kontextů se 43 jedinci a z luteránského hřbitova byl prozkoumán pouze jeden kontext se dvěma jedinci (obr. 10-11; podrobný rozpis viz v tab. 3). Z tabulky je zřejmé, že na plochách hřbitovů helvetského a luteránského šlo o málo početné hroby spíše „rodinného“ charakteru. Jiná situace byla zachycena na ploše vojenského hřbitova, kde nejen počet vícečetných hrobů, ale i množství jedinců v jednotlivých kontextech je nesrovnatelně vyšší.

\begin{tabular}{|c|c|c|}
\hline kontext & hřbitov & počet jedinců \\
\hline 0189 & vojenský & 36 \\
\hline 0204 & vojenský & 6 \\
\hline 0205 & vojenský & 140 \\
\hline 0207 & vojenský & 2 \\
\hline 0236 & vojenský & 1 \\
\hline 0309 & vojenský & 3 \\
\hline 0339 & vojenský & 76 \\
\hline 0383 & helvetský & 1 \\
\hline 0569 & helvetský & 1 \\
\hline 0570 & vojenský & 44 \\
\hline 0644 & helvetský & 1 \\
\hline 0675 & vojenský & 83 \\
\hline 0748 & helvetský & 5 \\
\hline 0816 & vojenský & 7 \\
\hline 0849 & helvetský & 2 \\
\hline 0900 & helvetský & 17 \\
\hline 0901 & luteránský & 1 \\
\hline 0902 & luteránský & 2 \\
\hline 0921 & helvetský & $?$ \\
\hline
\end{tabular}

Tab. 2. Kontexty obsahující doklady vápenného zásypu se zařazením do konkrétního hřbitova a s udáním počtu jedincủ, které daný kontext obsahoval.

Tab. 2. Kontexte, welche Belege für eine Kalkverfüllung enthalten mit Zuordnung zu einem konkreten Friedhof und Angabe der Anzahl der Individuen, die der betreffende Kontext enthielt.

\begin{tabular}{|c|c|c|}
\hline kontext & hřbitov & počet jedinců \\
\hline 0044 & vojenský & 2 \\
\hline 0189 & vojenský & 36 \\
\hline 0204 & vojenský & 6 \\
\hline 0205 & vojenský & 140 \\
\hline 0207 & vojenský & 2 \\
\hline 0249 & vojenský & 6 \\
\hline 0263 & vojenský & 2 \\
\hline 0268 & vojenský & 51 \\
\hline 0289 & vojenský & 5 \\
\hline 0309 & vojenský & 3 \\
\hline 0335 & vojenský & 2 \\
\hline 0339 & vojenský & 76 \\
\hline 0454 & vojenský & 21 \\
\hline 0559 & helvetský & 2 \\
\hline 0570 & vojenský & 44 \\
\hline 0598 & vojenský & 2 \\
\hline 0675 & vojenský & 83 \\
\hline 0748 & helvetský & 5 \\
\hline 0771 & helvetský & 3 \\
\hline 0816 & vojenský & 8 \\
\hline 0845 & helvetský & 2 \\
\hline 0849 & helvetský & 2 \\
\hline 0900 & helvetský & 17 \\
\hline 0902 & luteránský & 2 \\
\hline 0908 & helvetský & 2 \\
\hline 0939 & luteránský & 2 \\
\hline 0995 & helvetský & 2 \\
\hline 0999 & helvetský & 2 \\
\hline 1006 & helvetský & 4 \\
\hline 1022 & helvetský & 2 \\
\hline
\end{tabular}

Tab. 3. Přehled kontextů vícečetných hrobů s uvedenou lokací a počtem $\mathrm{v}$ nich pohřbených jedinců.

Tab. 3. Übersicht der Kontexte von Mehrfachgräbern mit Angabe der jeweiligen Lage und der Anzahl darin begrabener Individuen. 


\begin{tabular}{|c|c|c|c|c|c|c|}
\cline { 2 - 7 } \multicolumn{1}{c|}{} & \multicolumn{2}{|c|}{ vojenský } & \multicolumn{2}{c|}{ helvetský } & \multicolumn{2}{c|}{ luteránský } \\
\cline { 2 - 7 } & počet & $\%$ & počet & $\%$ & počet & 52 \\
\hline Z-V & 316 & 83,6 & 159 & 37,1 & 9 & 11,3 \\
\hline V-Z & 24 & 6,3 & 41 & 9,6 & 9 & 0 \\
\hline J-S & 8 & 2,1 & 132 & 30,8 & 0 & 6,3 \\
\hline S-J & 13 & 3,4 & 65 & 15,2 & 5 & 3,7 \\
\hline ostatní & 1 & 0,3 & 0 & 0 & 3 & 13,8 \\
\hline neurčená & 16 & 4,2 & 31 & 7,2 & 11 & 100,1 \\
\hline celkem & 378 & 99,9 & 428 & 99,9 & 80 & \\
\hline
\end{tabular}

Tab. 4. Orientace jedinců z jednočetných hrobů vzhledem ke světovým stranám.

Tab. 4. Orientierung der Individuen in den Einfachgräbern hinsichtlich Himmelsrichtung.

Absence intersticiální zeminy a stav kloubních spojení by odpovídaly současnému uložení zemřelých (např. Duday et al. 1990, 46; Rigeade 2007, 52; Duday 2009, 98). Šlo by o logický odraz doby, do které tento hřbitov spadal, a s ní spojených historických událostí. Vícečetné hroby jsou v prostředí křest’anské Evropy vnímány jako odchylky od „standardních“ pohřbů (např̀. Hutchinson-Mitchem 2001, 61; Castex 2008, 24). Tyto odchylky jsou nejčastěji zmiňovány v souvislosti s epidemiemi nemocí a válečnými událostmi a najdeme o nich zmínky v historických pramenech (např. Ariès 2000, 78-79).

Jednočetné pohřby byly zpravidla $\mathrm{v}$ souladu $\mathrm{s}$ tradičním křest’anským pohřebním ritem v natažené poloze v dorzálním dekubitu (vojenský $65,8 \%$, helvetský $81,3 \%$ a luteránský $74,1 \%$; srov. 1591 př́ípadů z 2151 pohřbených, tedy 74 \%, u kostela sv. Jakuba v Brně - Zůbek 2013, 68; srov. též Kostka-Šmolíková 1998, 830; Ariès 2000, 301). U ostatních jedinců většinou nebyla poloha a dekubitus určeny, nejčastěji kvůli stavu zachovalosti. Po jednom, maximálně dvou jedincích pak připadalo na ostatní charakteristiky, jako jsou skrčená poloha a ventrální či laterální dekubitus.

Orientace těl ke světovým stranám byla poměrně různá. Zatímco v př́ípadě vojenského hřbitova odpovídala křestanským, respektive katolickým standardům ve směru západ-východ (tab. 4), na luteránském hřbitově je počet pohřbů s touto orientací nízký, ačkoli převažující, a obdobné je to na helvetském hřbitově, kde se jí navíc početně blíží orientace jih-sever.

Při odkryvu a vyzvedávání koster byl věk dožití jedinců odhadován pouze do těchto věkových kategorií: fetus/neonatus, infans, juvenis, adultus-senilis, neodhadnuto. Př́ítomným antropologům bylo doporučeno, aby u nedospělých jedinců zaznamenávali vývoj zubů, stav osifikace kostry a měřili délky diafýz kostí typu dlouhého. Všechny tyto údaje poslouží jako podklady pro použití přesnějších a spolehlivějších metod odhadu věku dožití (např. podle mineralizace a prořezání zubů - metoda Ubelaker, 1989; podle stavu osifikace - metoda Ferembach et al., 1980; podle měření délek kostí - metoda Maresh, 1970). U dospělých jsme věk dožití blíže nespecifikovali.

Charakteru a funkci vojenského hřbitova odpovídalo i věkové složení pohřbené populace. Téměř všechny kosterní ostatky, 97,7\% (tab. 5), patřily dospělým a/nebo juvenilním jedincům a pouze $0,6 \%$ př́ípadů připadalo na plody, novorozence a děti. Plocha helvetského hřbitova vykazuje relativně menší podíl dospělých. Oproti tomu zde byl zachycen vysoký počet dětských pohřbů (pětina vyzvednutých ostatků; tab. 5) a dokonce relativně početné zastoupení nejmladších věkových kategorií fetus/neonatus. Na ploše luteránského hřbitova se ukázala silná převaha dospělých jedinců a děti jsou zastoupeny pouze 7\%, juvenilní jedinci dokonce jen 1,2\% (tab. 5). Možné vysvětlení lze hledat v prostorovém uspořádání hřbitova, kde dětem byla vyhrazena určitá konkrétní část (srov. Stloukal 1999, 366; Navrátilová 2004, 277), kterou jsme archeologickým výzkumem nezachytili. S ohledem na nekompletnost souboru a především předběžný charakter 
demografických dat (např. Stloukal 1999, 360-361), kdy nedisponujeme revidovaným odhadem pohlaví a přesnějším odhadem věku dožití (pouze ve zmíněných kategoriích fetus/neonatus, infans, juvenis a adultus-senilis), nelze u těchto souborů zatím konstruovat úmrtnostní tabulky. Pokud však výsledky jednotlivých hřbitovů srovnáme mezi sebou a dále s výsledky výzkumů u chrámu sv. Ducha v Hradci Králové (Víšková 2011, 57, tab. 1), u kostela sv. Mikuláše v Českých Budějovicích (Kuchař 2006, 32, tab. 1) a u kostela sv. Máří Magdalény v Plzni (Galeta a kol. 2015, 238), nelze si nepovšimnout velmi nízkého zastoupení nedospělých jedinců na vojenském, ale zejména luteránském hřbitově oproti hřbitovům v Hradci Králové a v Českých Budějovicích (tab. 6). U vojenského hřbitova je vysvětlením jeho funkce - byli zde pohřbíváni především vojáci, tedy dospělí, případně juvenilní muži. U luteránského hřbitova bychom mohli uvažovat spíše o prostorovém rozčlenění hřbitova pro různé sociální skupiny a nezachycení dětského oddělení (viz výše).

\begin{tabular}{|c|c|c|c|c|c|c|}
\cline { 2 - 7 } \multicolumn{1}{c|}{} & \multicolumn{2}{c|}{ vojenský } & \multicolumn{2}{c|}{ helvetský } & \multicolumn{2}{c|}{ luteránský } \\
\cline { 2 - 7 } \multicolumn{1}{c|}{} & počet & $\%$ & počet & $\%$ & počet & $\%$ \\
\hline fetus/neonatus & 1 & 0,1 & 25 & 5,3 & 3 & 3,5 \\
\hline infans & 4 & 0,5 & 101 & 21,5 & 3 & 3,5 \\
\hline juvenis & 172 & 19,8 & 13 & 2,8 & 1 & 1,2 \\
\hline adultus-senilis & 677 & 77,9 & 312 & 66,4 & 73 & 85,9 \\
\hline neodhadnuto & 15 & 1,8 & 19 & 4,0 & 5 & 5,9 \\
\hline
\end{tabular}

Tab. 5. Věkové složení v dokumentovaných hrobech jednotlivých zaniklých hřbitovů.

Tab. 5. Alterszusammensetzung in den dokumentierten Gräbern der jeweiligen verschwundenen Friedhöfe.

\begin{tabular}{|c|c|c|c|c|c|c|}
\cline { 2 - 7 } \multicolumn{1}{c|}{} & \multicolumn{5}{c|}{$\%$} \\
\cline { 2 - 7 } \multicolumn{1}{c|}{} & K-vojenský & K-helvetský & K-luteránský & $\begin{array}{c}\text { Hradec } \\
\text { Králové }\end{array}$ & $\begin{array}{c}\text { České } \\
\text { Budějovice }\end{array}$ & Plzeň \\
\hline nedospělí & 20,4 & 29,6 & 8,2 & 31,0 & 29,0 & 19,5 \\
\hline muži & 60,1 & 53,5 & 30,1 & 28,6 & 25,8 & 18,1 \\
\hline ženy & 4,7 & 13,8 & 24,7 & 25,4 & 37,1 & 20,0 \\
\hline neodhadnuto & 14,8 & 3,1 & 37,0 & 15,1 & 8,1 & 42,4 \\
\hline
\end{tabular}

Tab. 6. Srovnání demografické struktury (věk dožití a pohlaví) mezi zaniklými karlínskými hřbitovy a hřbitovy u chrámu sv. Ducha v Hradci Králové, u kostela sv. Mikuláše v Českých Budějovicích a u kostela sv. Máří Magdalény v Plzni. Tab. 6. Vergleich der demografischen Struktur (Überlebensalter und Geschlecht) zwischen den verschwundenen Friedhöfen von Karolinenthal und den Friedhöfen an der Heilig-Geist-Kathedrale in Hradec Králové, an der St. Nikolauskirche in České Budějovice und an der Maria Magdalenenkirche in Pilsen.

Odhad pohlaví byl v terénní části výzkumu prováděn u dospělých jedinců (tab. 7) - používali jsme pro něj dvě metody. Jednu založenou na pohlavních znacích pánevních kostí (Bruzek 2002) a druhou sledující pohlavní rozdíly na lebce (Buikstra-Ubelaker edd. 1994). Poměry mužů k ženám se na jednotlivých pohřebištích lišily. Na vojenském hřbitově, jak se dá očekávat, významně převažují muži. $\mathrm{V}$ jednočetných vojenských hrobech by ženy pravděpodobně mohly představovat rodinné prŕíslušnice vojáků z Invalidovny. Ženy se vyskytovaly i ve vícečetných vojenských hrobech, kde bychom o nich mohli uvažovat jako o doprovodu armády. Např́iklad v rámci Napoleonovy Grande Armée byly od roku 1805 ženy formálně integrovány do armády jako kantýnské, pradleny či markytánky (Signoli et al. 2004, 225). Zatímco převaha mužů na vojenském hřbitově nepřekvapuje, v případě helvetského vyvstane otázka po chybějících ženách. 
Jednou z možných hypotéz by opět bylo prostorové rozdělení hřbitova a nezachycení oddělení se ženskými pohřby při výzkumu. Oproti tomu výskyt obou pohlaví na luteránském hřbitově byl vyrovnaný, obdobně jako dokládají výsledky výzkumu ze hřbitova u chrámu sv. Ducha v Hradci Králové, kostela sv. Mikuláše v Českých Budějovicích či u kostela sv. Máří Magdalény v Plzni (tab. 6).

\begin{tabular}{|c|c|c|c|c|c|c|}
\cline { 2 - 7 } \multicolumn{1}{c|}{} & \multicolumn{2}{c|}{ vojenský } & \multicolumn{2}{c|}{ helvetský } & \multicolumn{2}{c|}{ luteránský } \\
\cline { 2 - 7 } \multicolumn{1}{c|}{} & počet & $\%$ & počet & $\%$ & počet & $\%$ \\
\hline M/M? & 407 & 60,1 & 167 & 53,5 & 22 & 30,1 \\
\hline F/F? & 32 & 4,7 & 43 & 13,8 & 18 & 24,7 \\
\hline I & 16 & 2,4 & 5 & 1,6 & 1 & 1,4 \\
\hline neodhadnuto & 222 & 32,8 & 97 & 31,1 & 32 & 43,8 \\
\hline
\end{tabular}

Tab. 7. Odhad pohlaví odkrytých jedinců na zkoumaných pohřebištích.

Tab. 7. Schätzung des Geschlechts der freigelegten Individuen auf den untersuchten Friedhöfen.

Ačkoli jsme v terénní části výzkumu do protokolů zaznamenávali i případné patologické změny a anatomické odchylky, nebudeme je v tomto příspěvku zmiňovat. Tyto nálezy vyžadují detailní laboratorní šetření, kterému nebylo možné se v terénu věnovat.

Vhodné je však zmínit doklady amputací, kraniálních pitev a trepanací (tab. 8). Pohřbení měli amputovány dlouhé kosti jak horních, tak dolních končetin (obr. 12:1). Z plochy vojenského hřbitova známe devět případů a $z$ helvetského čtyři případy. Na ploše luteránského hřbitova nebyl odkryt žádný doklad amputace. Ve většině prŕípadů se amputované končetiny nacházely $\mathrm{v}$ hrobě společně s jedincem. Lze se domnívat, že jedinec ze zmíněného kontextu zemřel během amputace nebo velmi krátce po jejím dokončení?

Poměrně četné byly nálezy rozříznutých lebek - kraniální pitvy (obr. 12:2-5). S těmi jsme se setkali na ploše vojenského hřbitova ve 42 prŕpadech, na helvetském ve 32 případech a na luteránském ve třech případech. Odříznuté kalvy bývaly uloženy v anatomických pozicích a jen $\mathrm{v}$ ojedinělých případech byla kalva na jiném místě v hrobě či dokonce nebyla přítomna. Stejný nález byl učiněn u kostela sv. Klimenta v Praze-Bubnech, kde ve třech př́ípadech z 50 pohřbených byla rozříznuta lebka a další kalvy byly nacházeny v zásypech (Kostka-Šmolíková 1998, 833).

Překvapivé byly doklady trepanací, které byly zachyceny ve třech případech na ploše helvetského hřbitova a $\mathrm{v}$ jednom prrípadě na luteránském hřbitově. Extrémní případ představovala kalva pokrytá deseti trepanačními otvory kontextu 0669 z helvetského hřbitova (obr. 12:3). vědy.

Uvedené př́ípady jsou zajímavé $\mathrm{z}$ hlediska pohřebního ritu a z pohledu historie lékařské

\begin{tabular}{|c|c|c|c|c|c|c|}
\cline { 2 - 7 } \multicolumn{1}{c|}{} & \multicolumn{2}{c|}{ vojenský } & \multicolumn{2}{c|}{ helvetský } & \multicolumn{2}{c|}{ luteránský } \\
\hline vnější zásahy & počet & $\%$ & počet & $\%$ & počet & $\%$ \\
\hline amputace & 9 & 1,04 & 4 & 0,84 & 0 & 0,00 \\
\hline kraniální pitva & 42 & 4,83 & 32 & 6,75 & 3 & 3,53 \\
\hline trepanace & 0 & 0,00 & 3 & 0,63 & 1 & 1,18 \\
\hline
\end{tabular}

Tab. 8. Vnější zásahy na kostrách.

Tab. 8. Äußere Eingriffe an den Skeletten. 


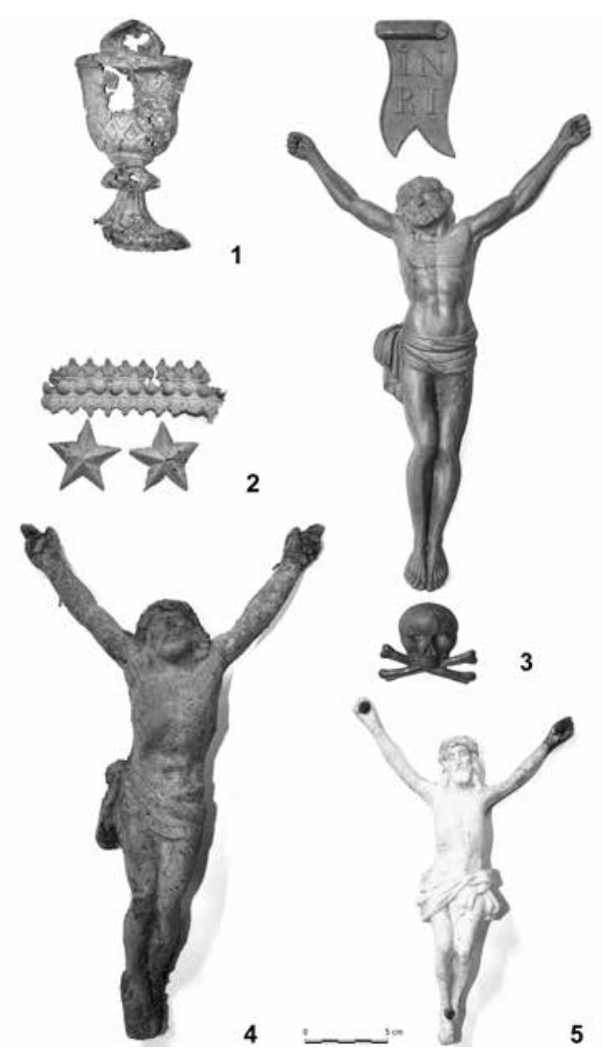

Obr. 8. Výzdoba na víkách dřevěných rakví. 1 - kalich z lisovaného plechu $z$ víka dřevěné rakve (0373); 2 - plechové aplikace $z$ dřevěné rakve (0538); 3 - korpus s titulem a Adamovou lebkou $z$ dřevěného kř́že na víku rakve (0810); 4 - litinový korpus z výplně prázdné rakve (0524); 5 - keramický korpus se železnými hřeby (0644). Foto P. Kacl. Abb. 8. Verzierung auf den Deckeln von Holzsärgen. 1 - Kelch aus Stanzblech vom Deckel eines Holzsarges (0373); 2 - Blechapplikation von einem Holzsarg (0538); 3 - Korpus Christi mit Initialen und Adamsschädel von einem Holzkreuz auf einem Sargdeckel (0810); 4 - Gusseiserner Korpus Christi aus der Verfüllung eines leeren Sargs (0524); 5 - Korpus Christi aus Keramik mit Eisennägeln (0644). Foto P. Kacl.

\section{Movité nálezy}

Při skrývce recentního navážkového souvrství byly ojediněle nalézány zlomky náhrobních kamenů. Nahodile se v něm vyskytly i lidské kosti a četně stavební keramika, zlomky keramických a skleněných nádob, kusy sklovité strusky, kovové předměty a další odpad.

U 41 nebožtíků z evangelických hřbitovů se zachovaly zbytky oděvu nebo obuvi. V několika př́ípadech bylo možno rozpoznat šaty a obleky s vázankami (obr. 6:2, 12:4, 13:4). V hrobě 0375 byly přítomny punčochy. U malých zbytků textilu není jasné, nepocházely-li z polstrování rakví. Častěji se z oděvů zachovaly součásti z trvanlivějších materiálů, tj. hlavně kovové, kostěné či skleněné knoflíky (obr. 12:4, 14:2-4), méně pak oděvní háčky a očka, špendlíky a přezky. 


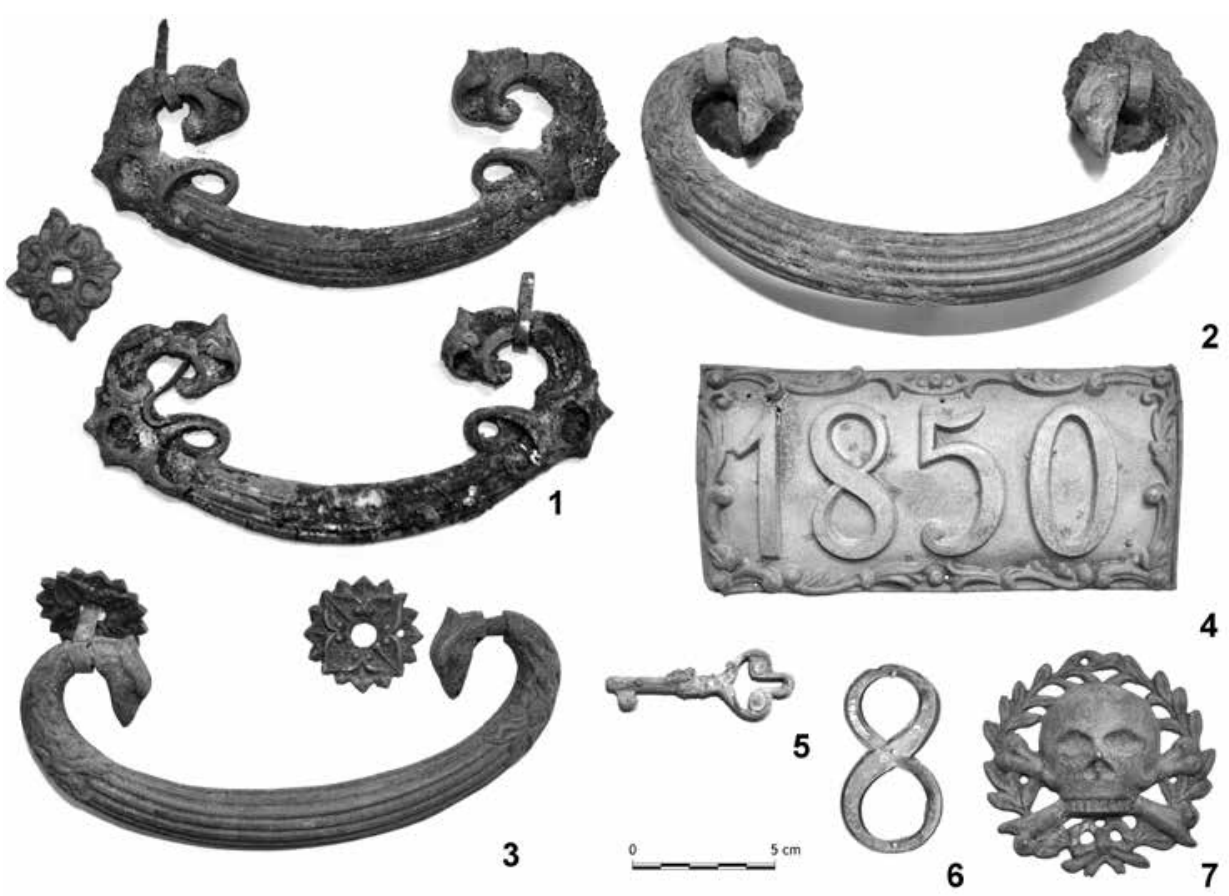

Obr. 9. Kovové součásti rakví. 1 - držadla z výplně hrobky G5 001; 2 - držadlo (0760); 3 - držadlo (0832); 4 - plechová tabulka s letopočtem (0758); 5 - klíček (0782); 6 - plechová číslice (zjišt’ovací sonda 100); 7 - aplikace s motivem Adamovy lebky (0760). Foto P. Kacl.

Abb. 9. Metallbestandteile der Särge. 1 - Griffe aus der Verfüllung von Gruft G5 001; 2 - Griff (0760); 3 - Griff (0832); 4 - Blechtafel mit Jahreszahl (0758); 5 - kleiner Schlüssel (0782); 6 - Blechziffer (Feststellungsgrabung Sondierschnitt 100); 7 - Applikation mit dem Motiv eines Adamsschädels (0760). Foto P. Kacl.

V hrobě 0635 se u hlavy dítěte nacházelo 179 skleněných korálků, zřejmě původně našitých na čelence.

Z hlediska přítomnosti předmětů osobní potřeby vyniká hrob 0522 (obr. 15). V kovové rakvi byla pochována žena ve vyšívaných šatech s krucifixem s dřevěnými ramínky kruhového průřezu ukončenými plechovými objímkami a s kovovým korpusem (obr. 17:13). Z dvojice zlatých náušnic nebyla část jedné nalezena (obr. 15:2). Dochována byla část účesu s hřebenem (z rohoviny či želvoviny; obr. 15:4), zubní protéza (obr. 15:3) a podrážky bot. Na oděvu ležely rozplavené drobné skleněné korálky.

Devocionálie, tedy předměty osobní zbožnosti, se v hrobech vyskytovaly poměrně často (obr. 13:1-2), a to zejména křižky a pohřební krucifixy (ze slitiny mědi, pravděpodobně mosazi [obr. 16], dřeva [obr. 17:10-11], kosti [obr. 17:1-4, 6-9], výjimečně z perleti [obr. 17:5], keramiky [obr. 18:1, 3] či sádry [obr. 18:2]), růžence či modlitební šňůry (z kosti, dřeva, klokočí, skla, kovu; obr. 18:4-8), méně pak medailky. Častěji se opakujícím motivem na medailkách bylo zjevení Panny Marie v Paříži Kateřině Zoe Labouré z 27. listopadu 1830. Razí se od roku 1832 a dosáhly značné oblíbenosti (Omelka-Šlancarová 2013, 84-85). Zřídka byly zjištěny ozdoby jako prsteny a náušnice. Do dětského hrobu 0375 byla přidána i prázdná knížečka o čtyřech listech, na nichž však nebyly ani stopy písma. Zřejmě šlo čistě o symbolický předmět.

Výzkumem bylo získáno tř́ináct mincí. Nejstaršími jsou tříkrejcar Karla VI. z roku 1717 ze zásypu hrobu 0637, měděný krejcar Marie Terezie nebo Štěpána Lotrinského z hrobu 0315 a krejcar Marie Terezie z roku 1762 ze zásypu hrobu 0364. Z masového hrobu 0268 (u jedinců 

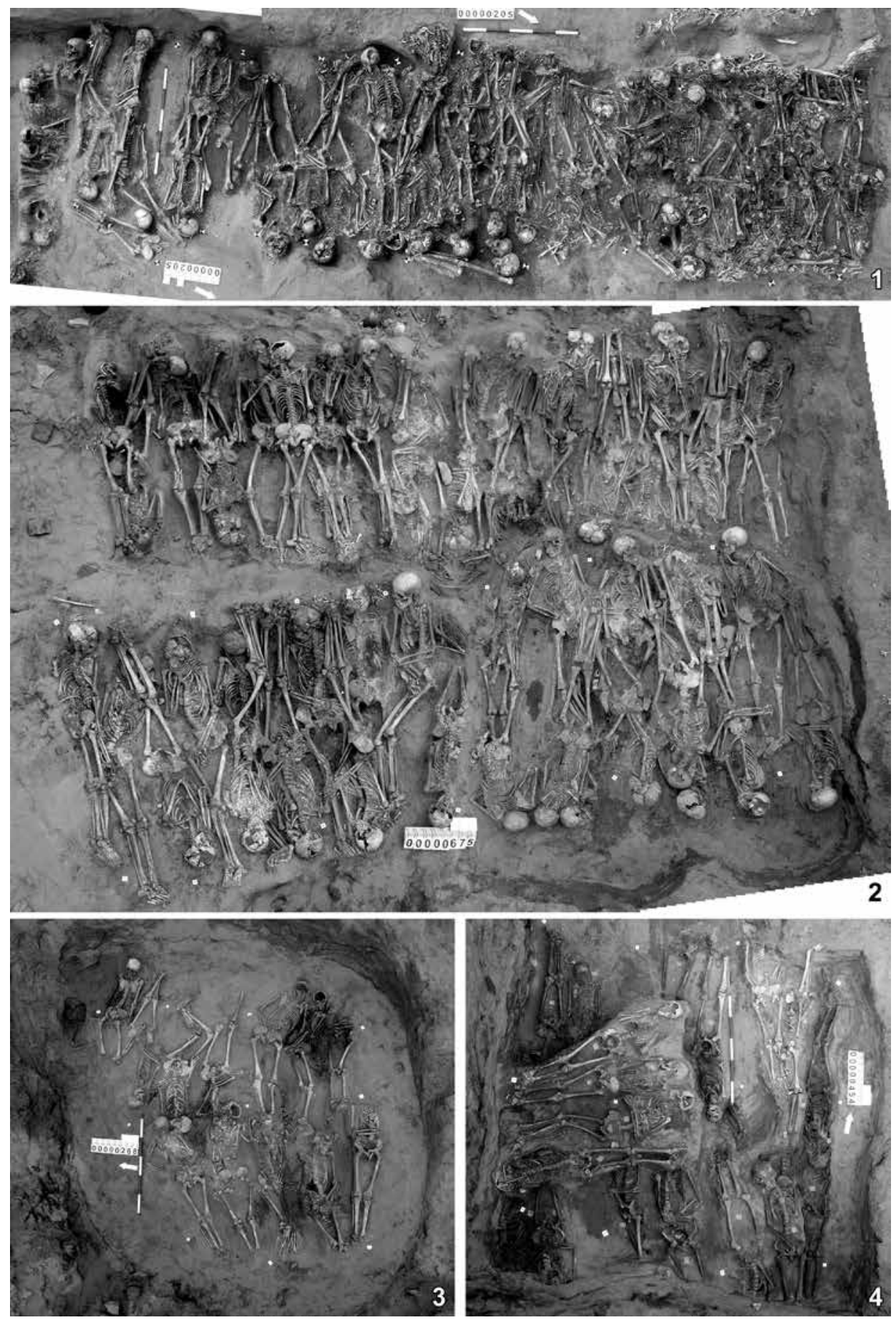

Obr. 10. Masové hroby. 1 - 0205; 2 - 0675; 3 - 0268; 4 - 0249/0454. Foto M. Dyčka (1), P. Kacl (2-4). Abb. 10. Massengräber. 1- 0205; 2 - 0675; 3 - 0268; 4 - 0249/0454. Foto M. Dyčka (1), P. Kacl (2-4). 


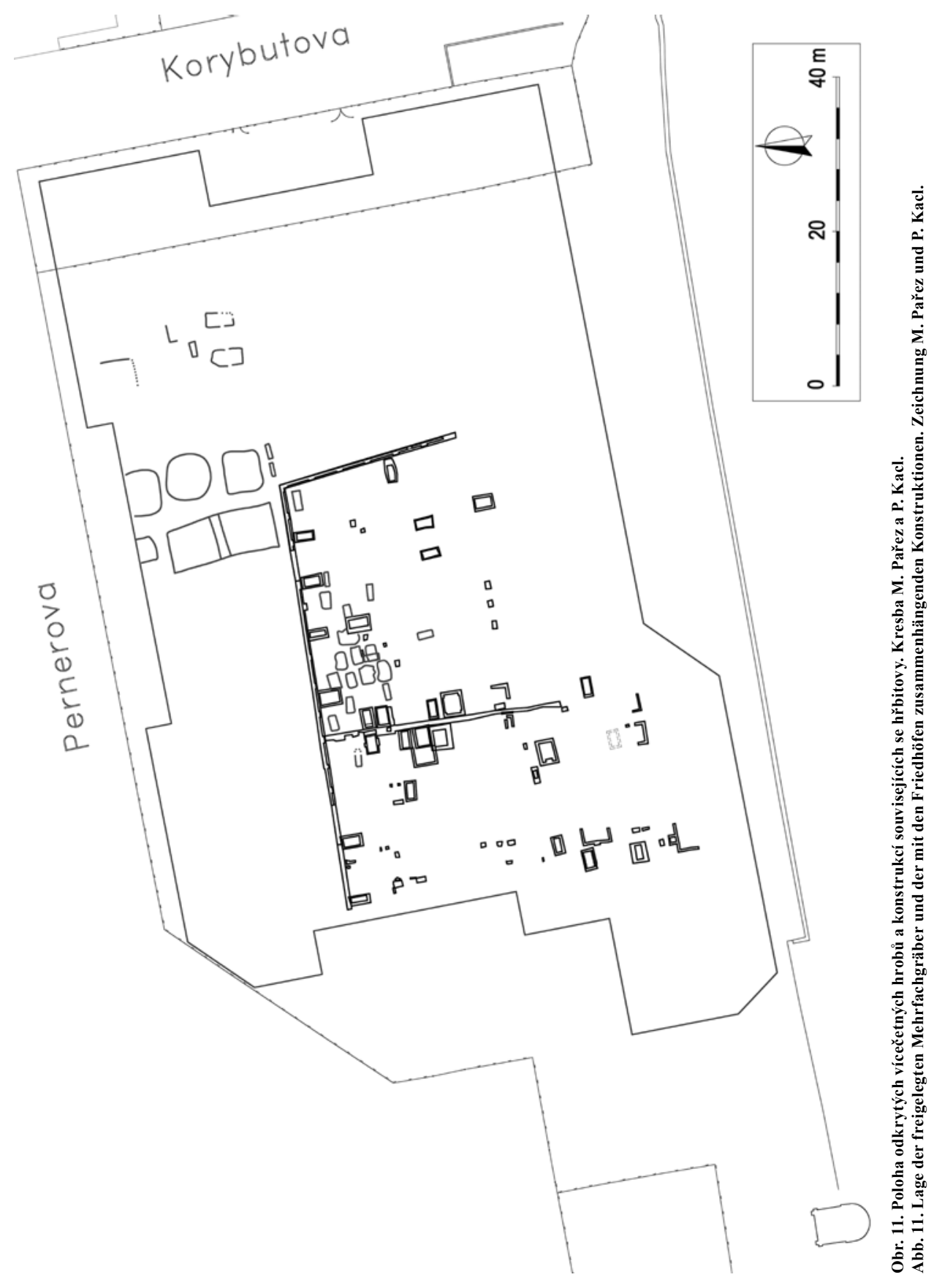



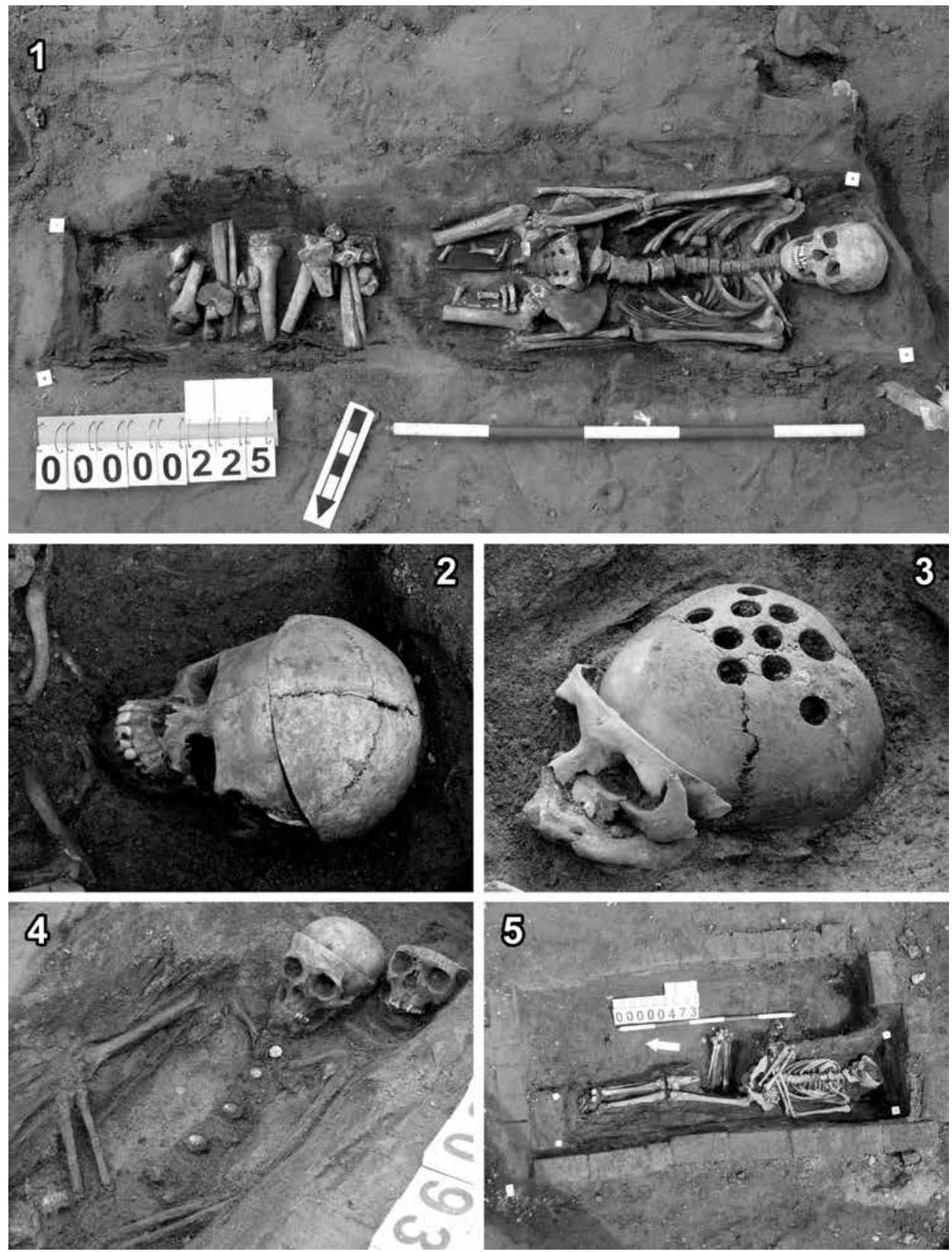

Obr. 12. Vybrané hroby s doklady pitev a trepanací. 1 - 0225; 2 - 0627; 3-0669; 4 -0939, do rakve byla přidána část lebky dalšího jedince; 5 - 0473, pohřeb v hrobové obrubě. Foto M. Dyčka (1), P. Kacl (2-4).

Abb. 12. Ausgewählte Gräber mit Belegen für Obduktionen und Trepanationen. 1 - 0225; 2 - 0627; 3 - 0669; 4 - 0939, in den Sarg wurde der Schädelteil eines weiteren Individuums hineingelegt; 5 - 0473, Begräbnis in einer Grabeinfassung. Foto M. Dyčka (1), P. Kacl (2-4). 

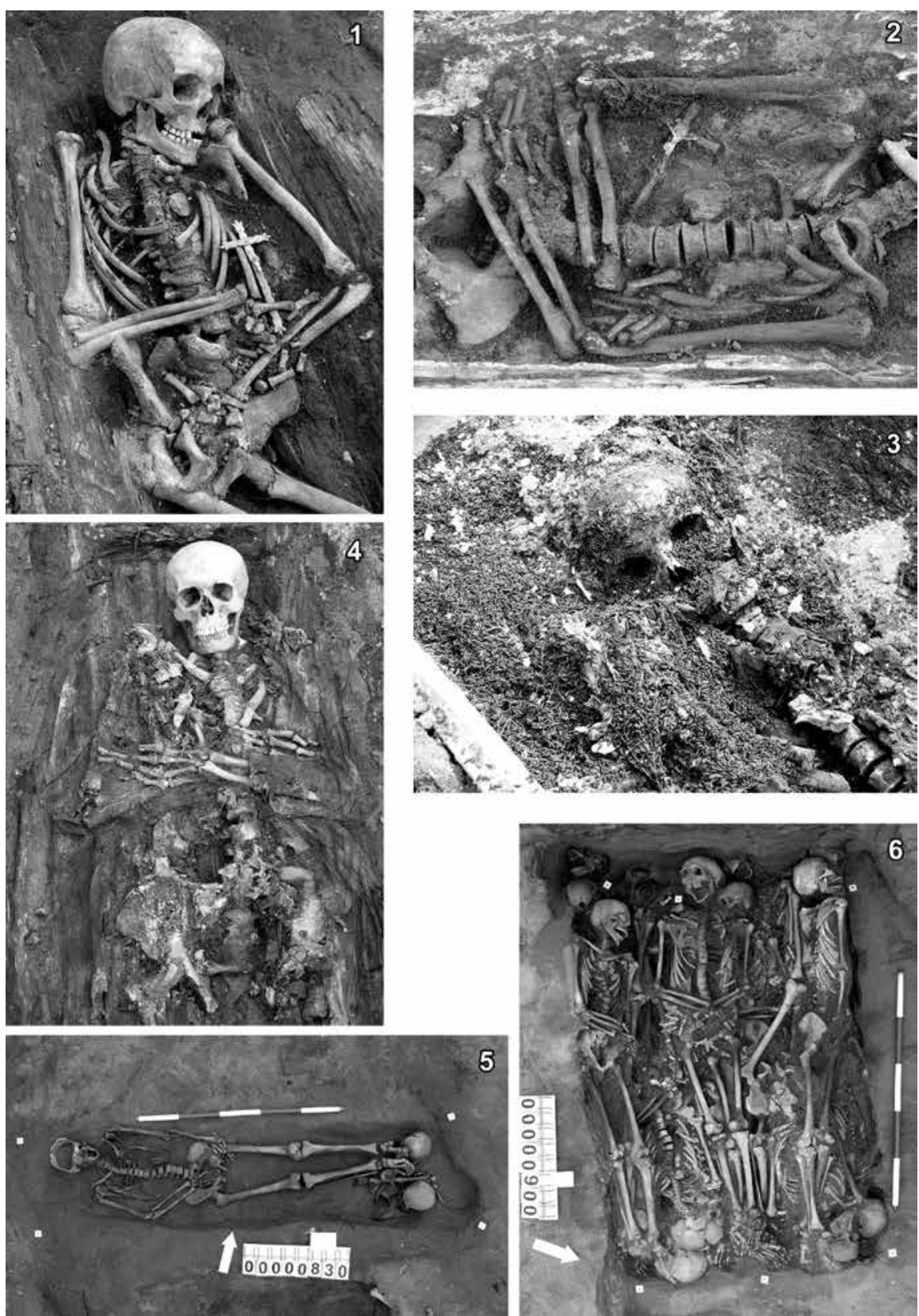

Obr. 13. 1 - 0642, pohřeb s kostěným krucifixem v ruce; 2 - 0826, krucifix $\mathrm{z}$ dřevěných a kovových součástí v oblasti břicha. 3 - 0653, pohřeb v kovové rakvi s částečně dochovaným textilem, s listnatými větvičkami a enormním množstvím muších pupárií; 4 - 0942, pohřeb s částečně dochovaným oděvem. 5 - 0830, pod rakví byly druhotně uloženy některé starší ostatky; 6 - masový hrob 0900. Foto P. Kacl.

Abb. 13. 1 - 0642, Begräbnis mit beinernem Kruzifix in der Hand; 2 - 0826, Kruzifix aus Holz- und Metalbestandteilen im Bereich des Bauches. 3 - 0653, Begräbnis in einem Metallsarg mit teilweise erhaltenem Textilstoff, mit Blätterzweigen und einer enormen Menge an Fliegenlarven; 4 - 0942, Begräbnis mit teilweise erhaltener Kleidung. 5 - 0830, unter dem Sarg waren einige ältere Gebeine sekundär beigesetzt; 6 - Massengrab 0900. Foto P. Kacl. 

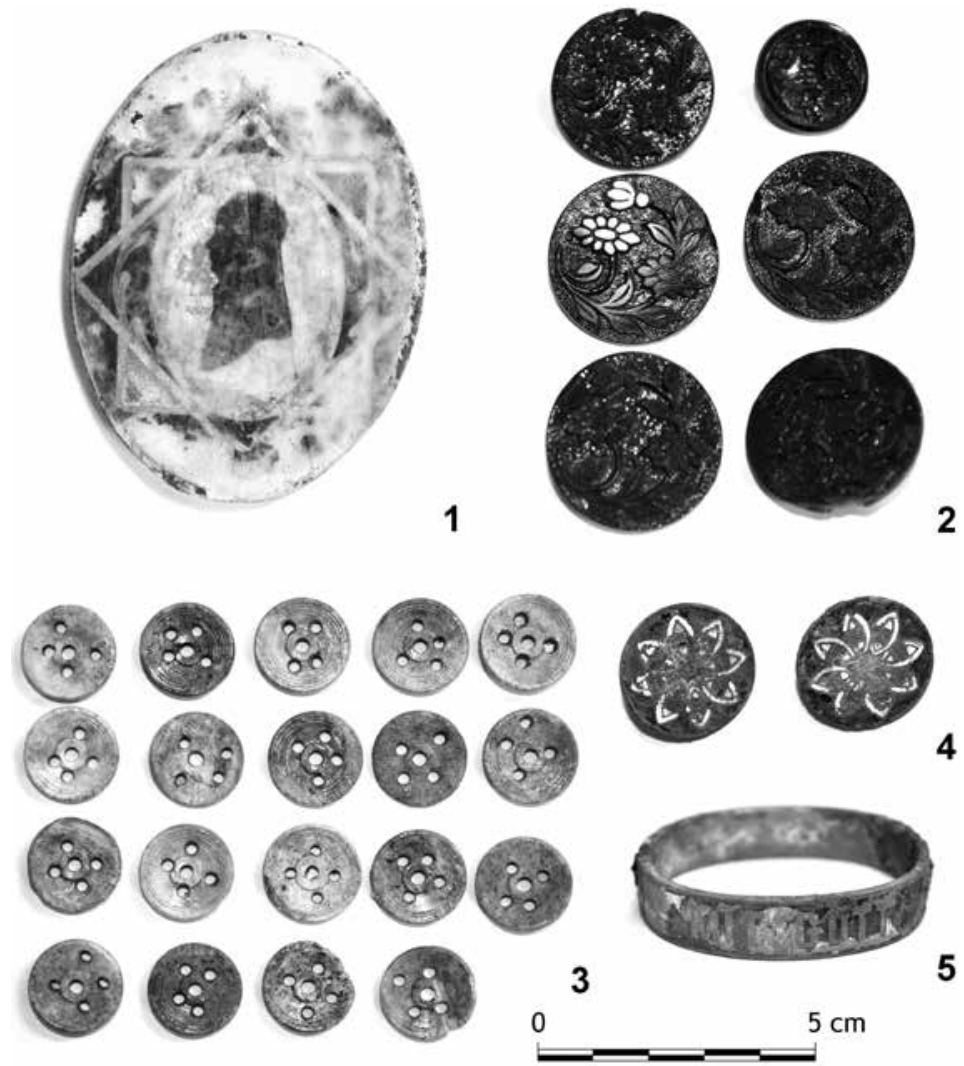

Obr. 14. Vybrané předměty hrobové výbavy. 1 - portrét z tmavé fólie a zlacení (?) mezi dvěma sklíčky (0506); 2 - reliéfně zdobené knoflíky z opakního černého skla (0563); 3 - kostěné knoflíky (0675-01); 4 - kovové knoflíky zdobené emailem (0740); 5 - malý kovový náramek s nápisem „Mit Gott“ (zjišt’ovací sonda 200). Foto P. Kacl.

Abb. 14. Ausgewählte Gegenstände der Grabausstattung. 1 - Porträt aus schwarzer Folie und Vergoldung (?) zwischen zwei Gläsern (0506); 2 - reliefverzierte Knöpfe aus schwarzem Opakglas (0563); 3 - beinerne Knöpfe (0675-01); 4 - mit Emaille verzierte Metallknöpfe (0740); 5 - kleines Metallarmband mit der Aufschrift „Mit Gott“ (Feststellungsgrabung Sondierschnitt 200). Foto P. Kacl.

0268-10, 0268-13, 0268-36) byly vyzvednuty tři měděné šestikrejcary Františka II. (na dvou je viditelný rok ražby 1800) a $\mathrm{z}$ dalšího masového hrobu 0189 pochází měděný krejcar Františka II. z roku 1800. Další krejcar téhož panovníka byl nalezen ve výplni nespecifikovaného hrobu ve čtverci G4. Na rakvi hrobu 0513 spočíval měděný půlkrejcar Františka Josefa I., jiný půlkrejcar z roku 1859 se nacházel v zásypu hrobu 0642 a třetí půlkrejcar Františka Josefa I. z roku 1885 byl nalezen při detektorovém průzkumu, jejž provedl Ing. Tomáš Prokop (Filozofická fakulta, Univerzita Hradec Králové) ve čtverci B5. Ze zásypu hrobu 0542 byl získán měděný krejcar Františka Josefa I. vyražený roku 1858.

Detektorovým průzkumem bylo objeveno mj. patnáct kusů munice (litých kulí a sekaného olova), které mohou souviset se soudobou existencí vojenské střelnice. Ta se východně a severovýchodně od hřbitovů měla nacházet již $\mathrm{k}$ roku 1823 a byla postupně přestavována a rozšiřována. Po roce 1874 se stala pražskou Posádkovou střelnicí a její zrušení nadešlo v roce 1901 (Heřmánek 2015, 32, 117-119, barevná př́iloha 2, 4-6). 

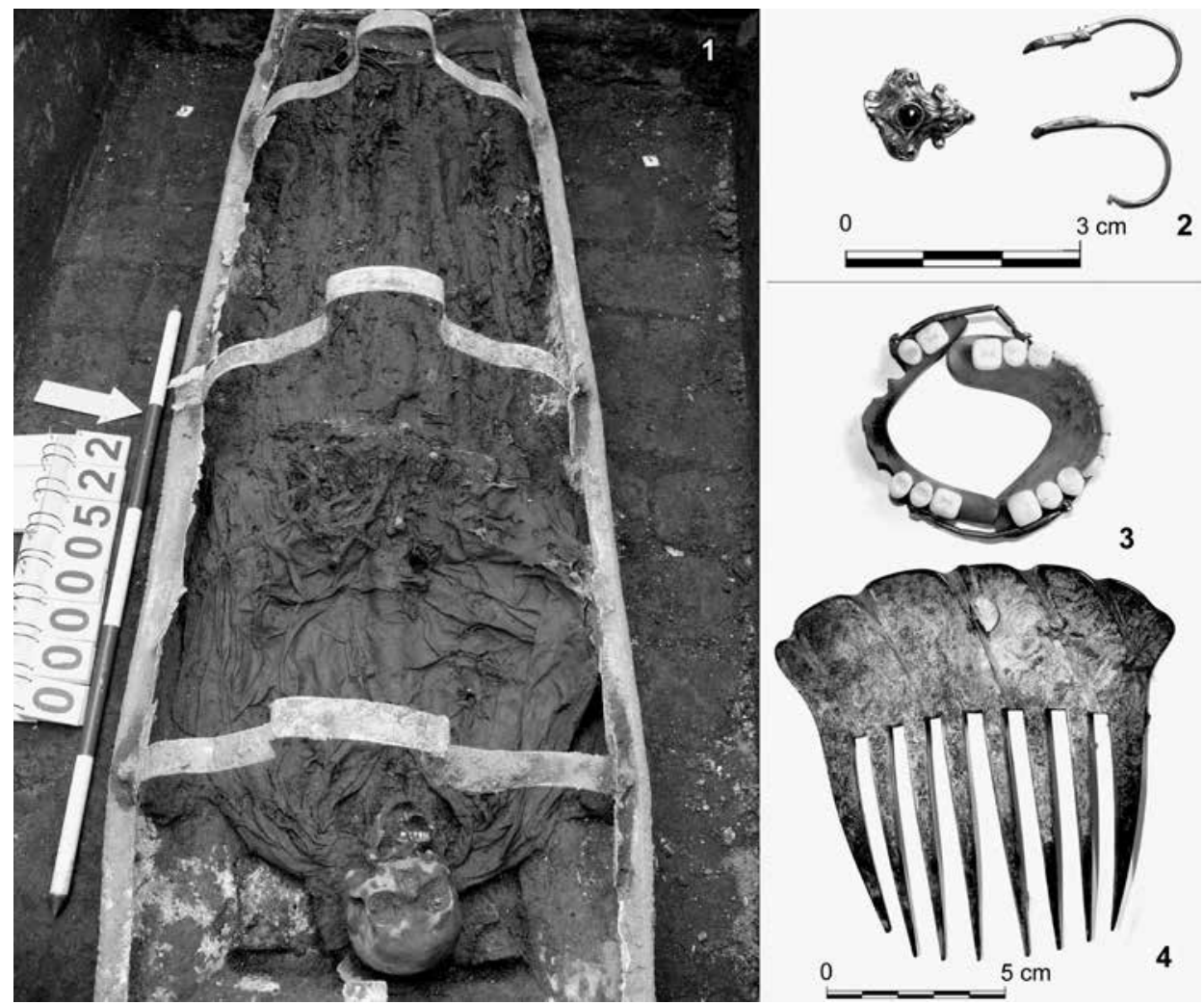

Obr. 15. Hrob 0522 ve zděné hrobce E5 001.1 - stav po odstranění vrchní části kovové rakve; 2 -zlaté (?) náušnice; 3 - zubní protéza; 4 - hřeben z rohoviny či želvoviny. Foto $P$. Kacl.

Abb. 15. Grab 0522 in der Mauergruft E5 001. 1 - Zustand nach Öffnung des oberen Teils des Metallsarges; 2 - Ohrringe aus Gold (?); 3 - Zahnprothese; 4 - Kamm aus Horn oder Schildpatt. Foto P. Kacl.

\section{Konstrukce}

Na celé odkryté ploše byly zdokumentovány stavební konstrukce (zakresleny jsou rovněž v obr. 2). V první řadě se to týká části opukové zdi (D4 001), vystavěné zřejmě v roce (nebo po roce) 1784 , jež oddělila tehdy nově vyčleněný prostor evangelických hřbitovů (obr. 19). Ve východní části se v ní nacházelo zamřížované okno, snad pro odtok vody (obr. 19:2). Mezi helvetským a luteránským hřbitovem byla později zbudována zed’ ze smíšeného materiálu, v severní části založená na dvou cihlových klenebních pasech (E5 005). K oběma těmto zdem (ale i mimo ně) byly na obou evangelických hřbitovech přistavovány, patrně v průběhu 19. století, cihlové hrobky. Jejich podzemních částí bylo na zkoumané ploše zachyceno dvacet. Podlahy mohly být jednoduché cihlové či zahlazené vrstvou malty (E3 001, E5 001, E8 001, E10 001, F5 001, F6 004, F8 001, G4 003, G5 001, G6 001, J11 011, K1 003, K5 002 [obr. 20:4], L1 004, L4 001, L5 001) nebo vydlážděny (E6 001 - E6 003, E9 003 - E9 005 [obr. 20:2], F6 001 - F6 002, H6 001 - H6 003 [obr. 20:1]). Pouze ve třech případech v hrobkách zůstali pohřbení jedinci (E5 001 - 0522, J11 001 - 0888, L1 004 - 0915, 0916), ve dvou př́ípadech rozpadlé dřevěné rakve (G5 001 - 1035 [spodek rakve], 1036 [spodek rakve s kostmi v neanatomické poloze], E9 003 1038 [zbytky prázdné rakve]). Všechny hrobky byly zasypány navážkami z doby planýrování 

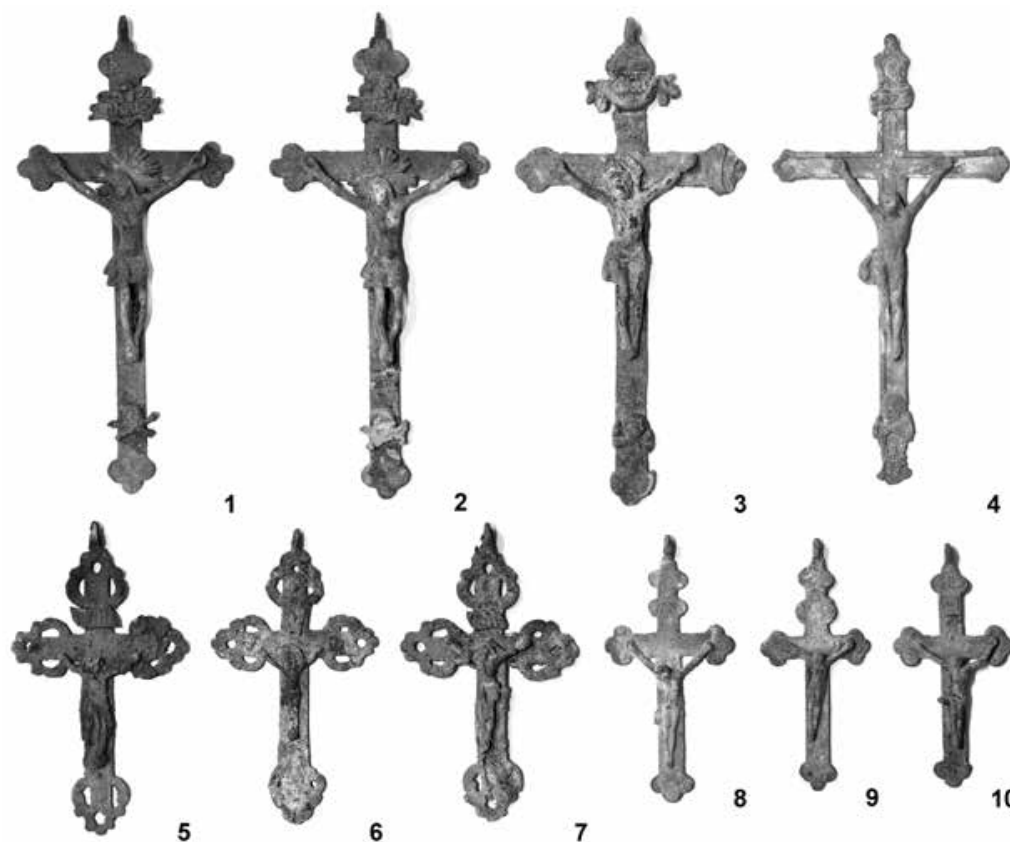

1

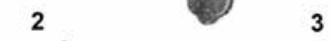

3
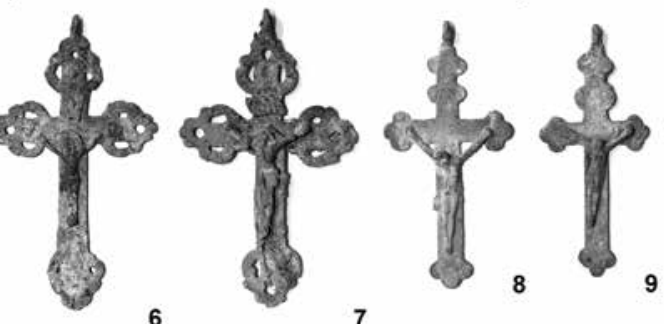

4

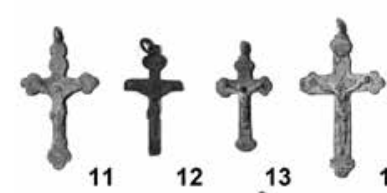

6
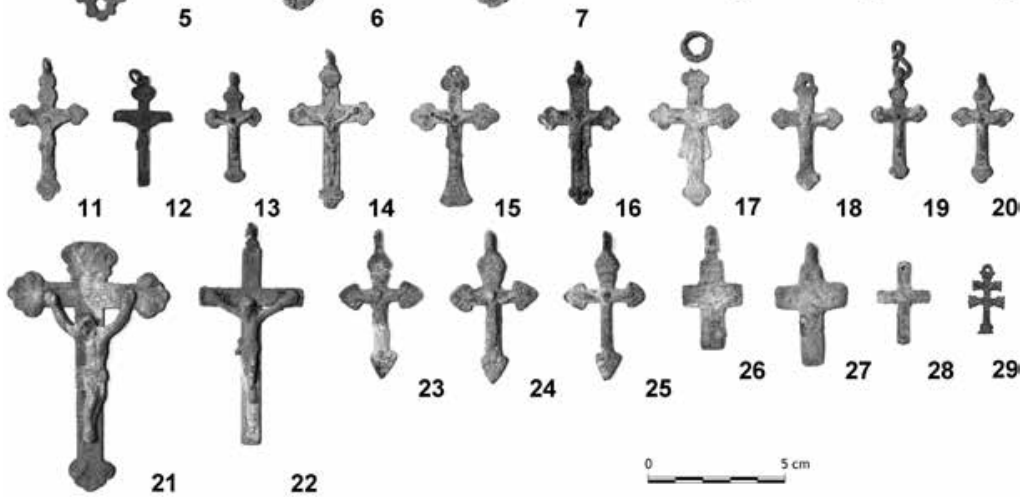

22

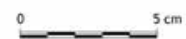

Obr. 16. Vybrané kříže ze slitiny mědi. 1 - 0260; 2 - E7 000; 3 - 0630; $4-0782 ; 5-0622 ; 6$ - 1005; 7 - 0767; 8 - 0278; 9 F9 000; $10-0023 ; 11-0630 ; 12-0071 ; 13-0574 ; 14-$ E11 000; $15-0138 ; 16-0963 ; 17-0216 ; 18-0317 ; 19-0688 ; 20$ 0719; 21 - 0612; 22 - 0496; 23 - 0251; 24 - 1028; 25 - D11 000; 26 - 0205-134; 27 - sběr; 28 - 0070; 29 - 0382. Foto P. Kacl. Abb. 16. Ausgewählte Kreuze aus Kupferguss. 1 - 0260; 2 - E7 000; 3-0630; 4 - 0782; 5 - 0622; 6 - 1005; 7 - 0767; 8 - 0278; 9 - F9 000; 10 - 0023; 11 - 0630; 12 - 0071; 13 - 0574; 14 - E11 000; 15 - 0138; 16 - 0963; 17 - 0216; 18 - 0317; 19 - 0688; 20 - 0719; 21 - 0612; 22 - 0496; 23 - 0251; 24 - 1028; 25 - D11 000; 26-0205-134; 27 - Begehung; 28 - 0070; 29-0382. Foto P. Kacl.

zrušeného hřbitova na počátku 20. století. Výplň hrobky G4 003 (G4 004) sestávala zejména z rozbitých keramických, skleněných a kovových nádob a dalšího odpadu (obr. 21, 22:1, 4) a poskytla i epigrafický doklad datování post quem k roku 1906 (zlomek porcelánového hrnku s nápisem a obrazovým motivem Výstavy německých Čech v Liberci; obr. 21:1). Fragment sklenice $\mathrm{z}$ modrého lisovaného skla s nápisem JUBILAEUM CÍSA ŘE PÁNA z výplně hrobky E8 001 (obr. 22:3) odkazuje k roku výroby 1888 (srov. Geiselberger 2003). Ze zásypů některých hrobek byly vyzvednuty fragmenty pískovcových náhrobků (např. částečně pozlaceného neoklasicistního v podobě stylizovaného antického chrámu [obr. 20:5]). 

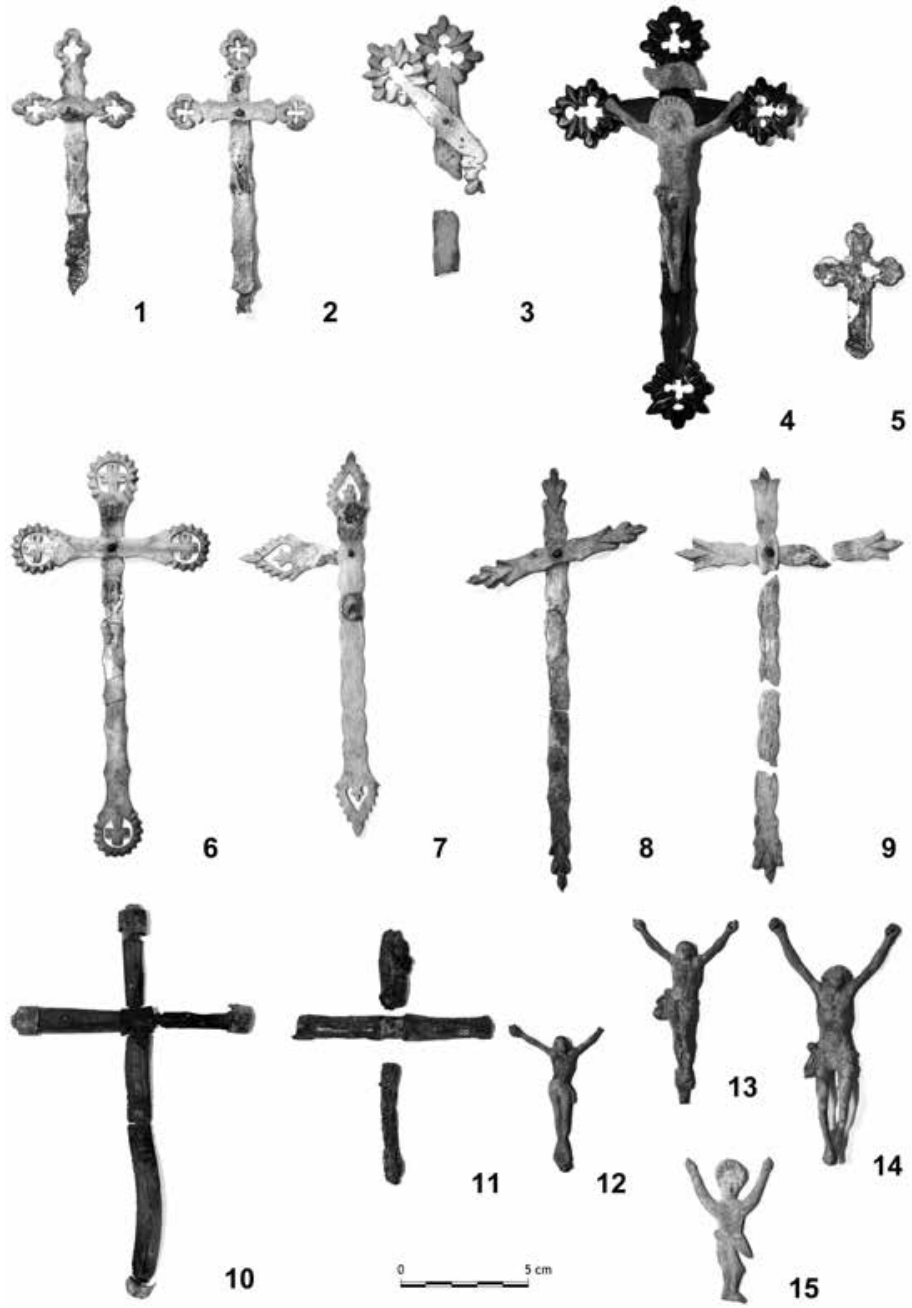

Obr. 17. Vybrané kř́ǐ̌e a jejich části z kosti. 1 - 0375; 2 - 0586; 3 - 0556; 4 - 0692; 6 - 0740; 7 - 0659; 8 - 0449; 9 - 0600. Kř́ǐ̌ z perleti. 5 - 0429. Kříže z dřeva s kovovými součástmi. 10 - 0888; 11 - 0382. Kovové korpusy. 12 - 0382; 13 - 0522; 14 - 0589; 15 - E7 000. Foto P. Kacl.

Abb. 17. Ausgewählte Kreuze und ihre aus Bein bestehenden Teile. 1 - 0375; 2 - 0586; 3- 0556; 4- 0692; 6 - 0740; 7 - 0659; 8 - 0449; 9 - 0600. Kreuz aus Perlmutt. 5 - 0429. Kreuz aus Holz mit Metallbestandteilen. 10 - 0888; 11 - 0382. Korpuse Christi aus Metall. 12 - 0382; 13 - 0522; 14 - 0589; 15 - E7 000. Foto P. Kacl.

Dalším typem konstrukcí byly tzv. hrobové obruby, obdélná vyzdění vrchní části hrobových jam (obr. 12:5). Na rozdíl od hrobek zde po pohřbu nezůstal dutý prostor, celá hrobová jáma byla zaházena zeminou. Obrub hrobových jam bylo zachyceno osm, možná devět. Jedna se odlišovala použitým materiálem, který namísto obvyklých cihel tvořily hlavně kamenné prvky (F4 001).

S funerální komponentou souvisely i základy podstavců pod náhrobky přibližně obdélných či čtvercových půdorysů z cihel, dlaždic či kamenů (někdy i druhotně použitých zlomků náhrob- 

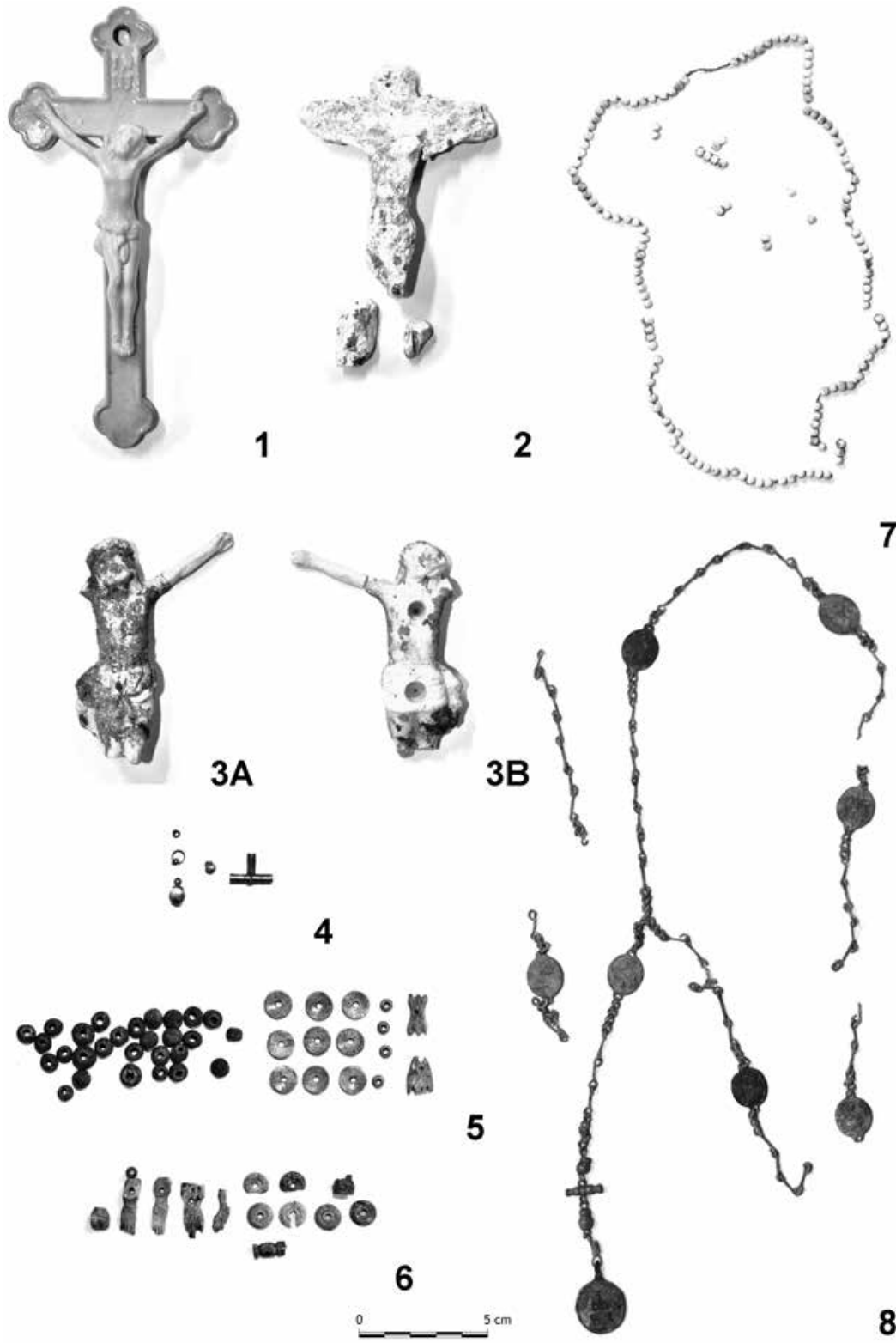

Obr. 18.1 - krucifix z glazované keramiky (0237); 2 - krucifix ze sádry (0340); 3 - korpus z keramiky (0374); 4 - části rủžence s credo křížkem (0420); 5 - hliněné a kostěné korálky (včetně typu arma Christi) z růžence (0454-08); 6 - kostěné korálky a součásti růžence včetně arma Christi a části credo křížku (0675); 7 - růženec z hliněných korálků (0375); 8 - růženec ze slitiny mědi s medailkami s motivy Panny Marie Sedmibolestné a s kostěnými částmi credo křižku (0815). Foto P. Kacl. Abb. 18. 1 - Kruzifix aus glasierter Keramik (0237); 2 - Kruzifix aus Gips (0340); 3 - Korpus Christi aus Keramik (0374); 4 - Teil eines Rosenkranzes mit Credo-Kreuz (0420); 5 - Perlen aus Ton und Bein (einschließlich des Typs Arma Christi) von einem Rosenkranz (0454-08); 6 - beinerne Perlen und Rosenkranzbestandteile einschließlich Arma Christi und Teile eines Credo-Kreuzes (0675); 7 - Rosenkranz aus Tonperlen (0375); 8 - Rosenkranz aus Kupferguss mit Medaillons mit dem Motiv Jungfrau Maria der sieben Schmerzen und beinerne Teile eines Credo-Kreuzes (0815). Foto P. Kacl. 

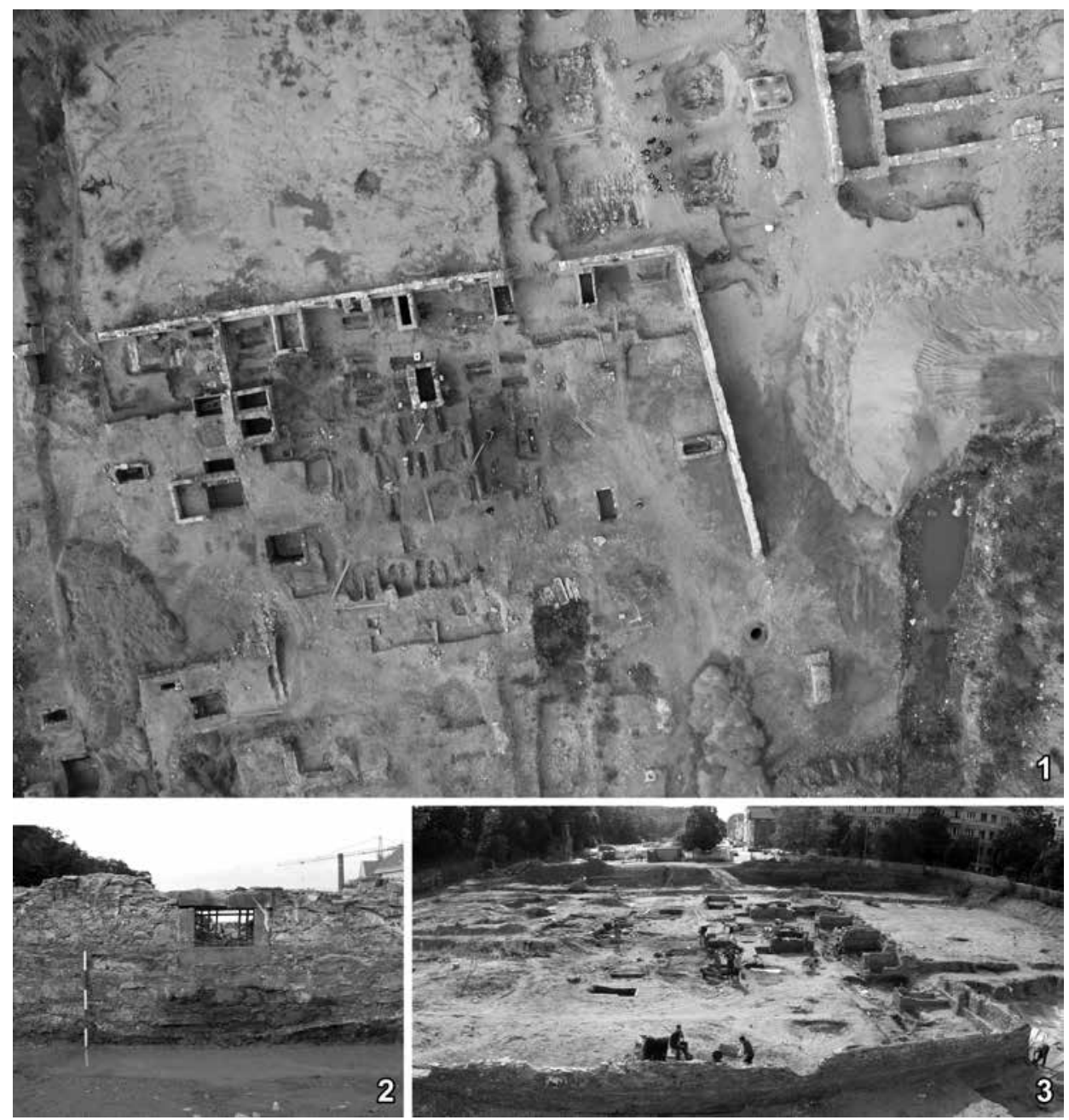

Obr. 19. 1 - snímek z průběhu terénní části výzkumu s odkrytými konstrukcemi a některými hroby; 2 - zamřížovaný otvor v opukové ohradní zdi evangelických hřbitovů (D4 001); 3 - pohled na odkrývanou část evangelických hřbitovů od západu. Foto J. John (1), P. Kacl (2, 3).

Abb. 19. 1 - Aufnahme vom Verlauf des Geländeteils der Grabung mit freigelegten Konstruktionen und einigen Gräbern; 2 - Vergitterte Öffnung im Plänermauerwerk der Einfriedungsmauer der evangelischen Friedhöfe (D4 001); 3 - Blick auf den freigelegten Teil der evangelischen Friedhöfe von Westen. Foto J. John (1), P. Kacl (2, 3).

ků; obr. 20:3). Zachyceno jich bylo třicet jedna. Tři takové konstrukce (F3 001, F4 004, F4 005) jasně souvisely s hrobem 0817 (obr. 7:1).

Fragmenty dvou pískovcových náhrobků nesly nápisy s vročením do let 1810 (obr. 20:6) a 1796 (v tomto druhém případě navíc s reliéfní výzdobou). Vyskytly se rovněž kusy funerální figurální plastiky.

Opuková zdiva, hluboce založená do pískového podloží, včetně sklepa (A16 002), nacházející se v severovýchodní části plochy souvisejí s vývojem po roce 1905 a s obecní zahradou. Tyto budovy lze spatřit na dobových plánech (např. Míka 2011, vložená př́loha). Při hloubení výkopů 

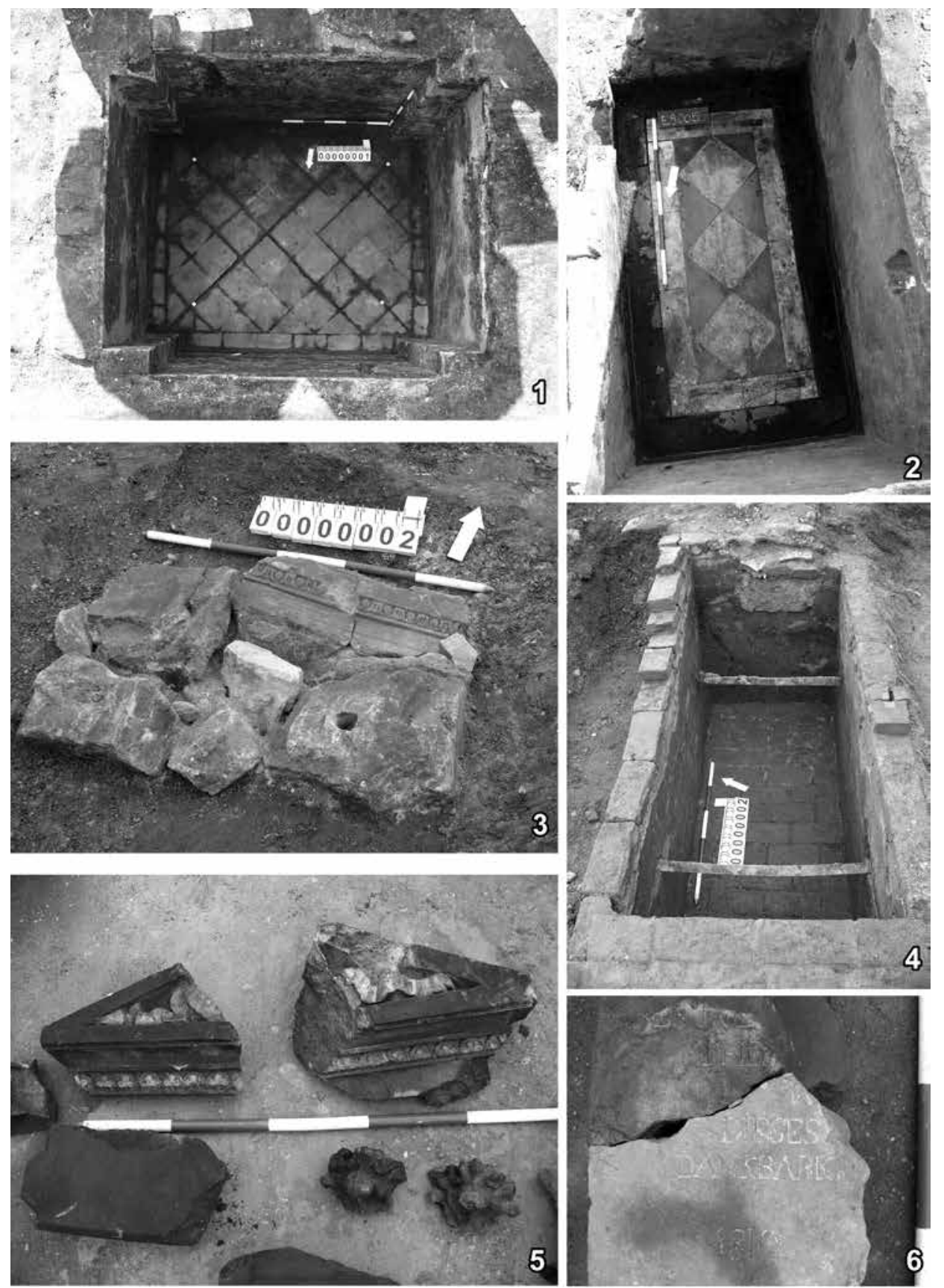

Obr. 20.1 - hrobka H6 001 s dlážděním; 2 - hrobka E9 003 s dlážděním; 3 -zpevnění základu pro pomník I8 002 s druhotně použitými zlomky funerální architektury; 4 - hrobka $\mathrm{K} 5002$ s cihlovou podlahou; 5 - fragmenty neoklasicistního náhrobku z pískovce se zlacením ze zásypu hrobky F5 001; 6 - fragmenty pomníku s letopočtem 1810. Foto P. Kacl.

Abb. 20. 1 - Gruft H6 001 mit Pflasterung; 2 - Gruft E9 003 mit Pflasterung; 3 - Befestigung des Unterbaus für Denkmal I8 002 mit sekundärer Verwendung von Bruchstücken der Funeralarchitektur; 4 - Gruft K5 002 mit Ziegelsteinboden; 5 - Fragmente eines neoklassizistischen Grabsteins aus Sandstein mit Vergoldung aus der Gruftverfüllung F5 001; 6 - Fragment eines Denkmals mit Jahreszahl 1810. Foto P. Kacl. 


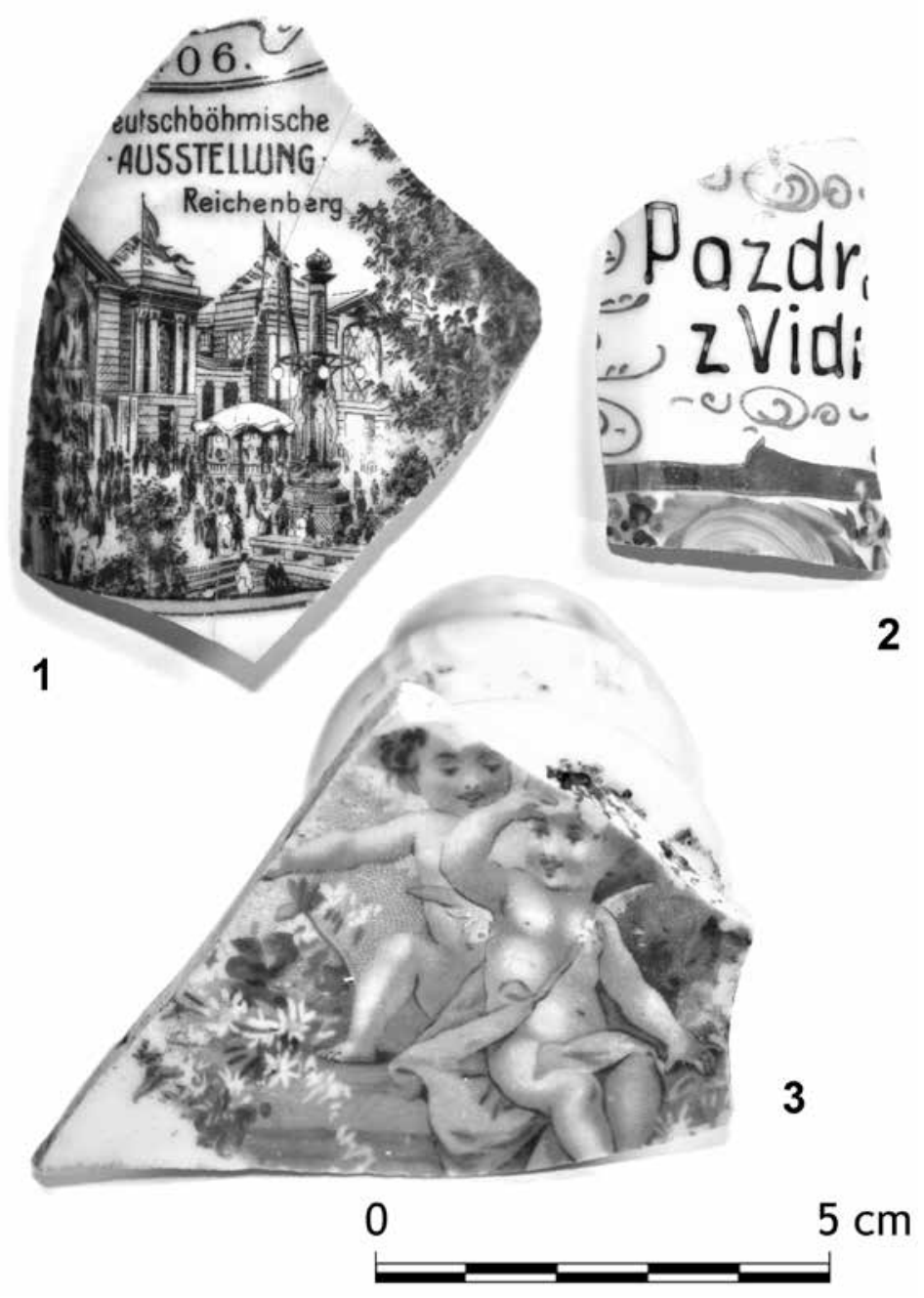

Obr. 21. Zlomky keramických nádob ze zásypu hrobky G4 003. Foto P. Kacl.

Abb. 21. Bruchstücke von Keramikgefäßen aus der Verfüllung von Gruft G4 003. Foto P. Kacl.

pro jejich základy byla narušena řada hrobů. Patrně i studna J12 001 vznikla později v rámci úprav pozemku pro obecní a pokusnou zásobní zahradu.

Byly zdokumentovány i zbytky některých stavebních konstrukcí recentních (K5 001, K6 001, L5 003) a některých nejasného stáŕí a účelu (G4 001, I6 001, M1 001).

\section{Závěr}

Výzkum v Karlíně jednoznačně potvrdil přítomnost značného množství hrobů, které na hřbitovech zůstaly po jejich zrušení. Exhumace vojenských hrobů, které probíhaly v letech 1904 a 1905, se týkaly údajně pěti tisíců hrobů, přičemž většina ostatků, okolo čtyř tisíců osob, měla být vyzvednuta na hřbitově pro mužstvo a jeden tisíc na důstojnickém hřbitově (Michálková- 

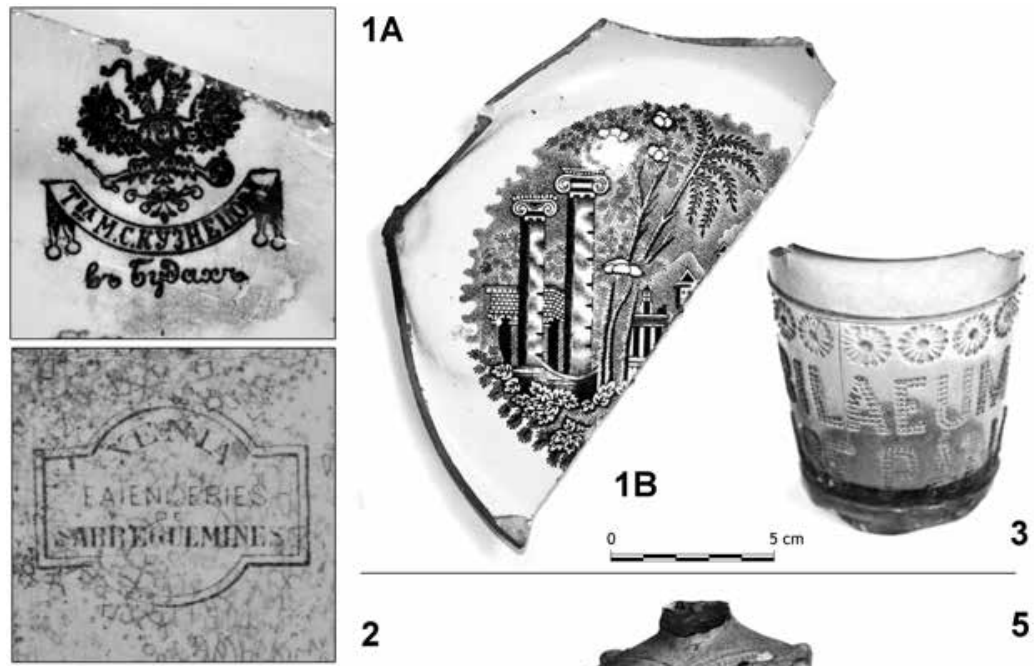

\section{2}
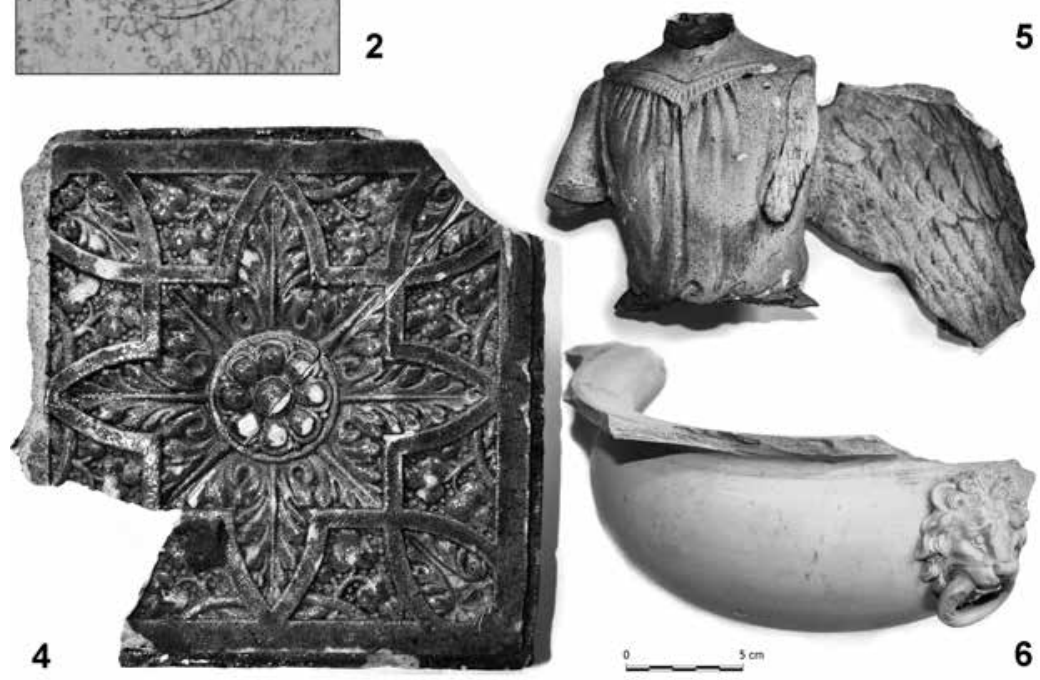

Obr. 22. Vybrané nálezy ze zásypů hrobek E5 001, E8 001, G4 003 a G5 001. 1 - zlomek fajánsové mísy se značkou Kuzněcovovy továrny v Budách (1894-1917); (G4 004); 2 - značka továrny na fajánsové zboží Xenia v Sarreguemines (Saargemünd); (E5 002); 3 - sklenice z modrého lisovaného skla s nápisem „Jubilaeum Císaře Pána“ (E8 002); 4 - glazovaný kachel s kolkem kamnáře J. Našince z pražské Malé Strany na vnitřní straně (G4 004); 5 -zlomek keramické okřídlené figury (G5 002); 6 - zlomek keramického květináče se lvím maskaronem (E8 002). Foto P. Kacl.

Abb. 22. Ausgewählte Funde aus den Verfüllungen der Gruften E5 001, E8 001, G4 003 und G5 001.1 - Bruchstück einer Fayanceschale mit Marke der Kuznetzov-Fabrik in Budy (1894-1917); (G4 004); 2 - Fabrikmarke auf Fayanceware mit dem Muster Xenia aus Sarreguemines (Saargemünd); (E5 002); 3 - Glas aus blauem Pressglas mit der Aufschrift „Jubilaeum Císaře Pána“ (E8 002); 4 - Glasurkachel mit Stempelmarke des Ofenbauers J. Našinec von der Prager Kleinseite auf der Innenseite (G4 004); 5 - Bruchstück einer beflügelten Keramikfigur (G5 002); 6 - Bruchstück eines Keramikblumentopfes mit Löwenmaskaron (E8 002). Foto P. Kacl.

Michálek 2008, 107). Je pravděpodobné, že ony čtyři tisíce exhumovaných hrobů se nalézaly v nejsvrchnějších partiích terénu nebo byly tzv. biologicky aktivní. Na evangelických hřbitovech byla nejzjevnější absence pohřbů ve většině hrobek.

V souvislosti s historickými zmínkami je třeba formulovat několik postřehů. Navzdory svému relativně novodobému založení a nedlouhé době fungování (asi sto čtyřicet let) prodělalo pohřebiště několik dispozičních změn. Není známo, v jakém rozsahu byl hřbitov pro invalidy, 
vysloužilce a jejich rodiny založen. Na konci roku 1753 pak byl c. k. pražským hospodářským ředitelstvím založen vojenský ,hřbitov s kapli a kostnici“. Pohřebiště kromě invalidů a jejich rodin začalo sloužit celé pražské vojenské posádce, mužstvu i důstojníkům (Kneidl 1923, 271; Michálková-Michálek 2008, 65, 69). Vzhledem k poloze kaple se zdá zřejmé, že oba evangelické hřbitovy, zřízené roku 1784, vznikly na volných pozemcích východně od hřbitova vojenského. Spojitost masových hrobů 0900 a 1028-1034 (neprozkoumaných) s válečnými událostmi 40.-60. let 18. století se tak zdá nanejvýše nepravděpodobná. Z hlediska horizontální stratigrafie potvrzuje založení evangelických hřbitovů na volných pozemcích a postupné rozšiřování celého komplexu fakt, že hroby respektovaly ohradní zed' D4 001.

Podle některých dobových plánů (Míka 2011, obr. 40, 58) se zdá, že východní část vojenského hřbitova mohla být připojena až někdy mezi lety 1816 a 1840.

Otázkou je, kam a o kolik se rozšírily evangelické hřbitovy snad v roce 1833 , určitě potom v roce 1863 (Michálková-Michálek 2008, 68-69). K polovině 19. století byly stále ještě volné parcely s tehdejšími čísly 100 a 101, vedené jako zahrada a pastvina, obklopené z jihu svahem Vítkova a ze zbylých tří stran hřbitovy. Nabízí se tedy úvaha, že právě ony mohly být k evangelickým hřbitovům připojeny. V druhé polovině 19. století již pohřebiště tyto pozemky pokrývalo. Dobové mapy však neposkytují jasné vodítko, zda se na pozemcích ppč. 100 a 101 nacházel hřbitov evangelický, nebo vojenský (srov. Semotanová a kol. 2016, obr. na s. 275 dole, obr. na s. 357, obr. na s. 422-423, obr. na s. 424). Na pláncích z let 1903 (ale ani z roku 1874) tato plocha není odlišena od vojenského hřbitova pro mužstvo (Michálková-Michálek 2008, obr. na s. 137; Heřmánek 2015, obr. na s. 116). O rekonstrukci postupného rozšiřování hřbitovního komplexu se pokoušíme na obr. 23 .

Jak víme $\mathrm{z}$ písemných pramenů, k pochovávání enormního množství zemřelých došlo po bitvách u Drážd’an a u Chlumce v srpnu roku 1813, po nichž následoval do Prahy mohutný příval raněných z vojsk spojeneckých, tj. Rakušanů, Prusů a Rusů, i z nepřátelské francouzské armády. V průběhu podzimních měsíců roku 1813 pak na karlínském vojenském hřbitově kopalo hroby každý den padesát vězňů, v prosinci jich stačilo denně již jen čtyřicet, někdy dvacet (Michálková-Michálek 2008, 71-73). S největší pravděpodobností je možno velké masové hroby 0189, 0204, 0205, 0249, 0268, 0339, 0570, 0675 (ale zřejmě i některé menší) ztotožnit se zmíněnými válečnými události roku 1813. Oporu tomu poskytují tř́i šestikrejcary Františka II. z hrobu 0268 a krejcar téhož panovníka z hrobu 0189. Šachtové hroby byly však kopány i za prusko-rakouské války v roce 1866, kdy již hřbitov kapacitně nedostačoval, jejich poloha ani počet však nejsou, s výjimkou (přemístěného) pomníku 285 padlých pruských vojáků, obnoveného v roce 1896, známy (Leonhardt 1905, 18; Michálková-Michálek 2008, 77-79). Zajímavý je fakt, že vícečetný hrob 0816 byl narušen výkopem stejně hluboko zasahujícího hrobu 0205. Masové hroby se $\mathrm{v}$ jiných případech vzájemně respektovaly (obr. 11). Zcela výjimečně byla do masových hrobů uložena i těla v dřevěných rakvích - dětský pohřeb 0759 do spodní úrovně hrobu 0205 a pohřeb dospělého jedince do jedné z vrchních úrovní hrobu 0339.

Pohřební ritus se výrazně nelišil od běžně praktikovaného dobového křestanského způsobu. Většina jedinců byla uložena ve standardní natažené poloze na zádech. Výjimky se vyskytovaly především $\mathrm{v}$ hromadných hrobech, kde jiné polohy byly pravděpodobně důsledkem manipulace se zemřelými (jejich naházení do jam). Odchylky lze sledovat při orientaci těl vzhledem ke světovým stranám, a to především na ploše helvetského hřbitova. Vzhledem k funkci se vojenský hřbitov výrazně odlišoval v demografické struktuře pohřbených jedinců velmi nízkým zastoupením nedospělých jedinců a žen. Zatímco na ploše helvetského hřbitova bylo poměrně vyšší zastoupení nedospělých jedinců, zato nízké zastoupení žen oproti mužům, na ploše luteránského hřbitova vyšlo najevo nízké zastoupení nedospělých a rovnoměrný podíl žen vůči mužům. Možným vysvětlením těchto diskrepancí by mohlo být prostorové rozčlenění hřbitovů pro různé sociální skupiny nezachycené ve vzorku archeologického výzkumu.

Dochované terény hřbitova se nacházejí i jinde ve svém někdejším rozsahu. V roce 1999 provedl M. Kostka (Muzeum hlavního města Prahy) záchranný výzkum v prostoru kanalizační šachty na ppč. 826 před jižním nárožím domu čp. 536 v Pernerově ulici. V hloubce 3,2 metru 


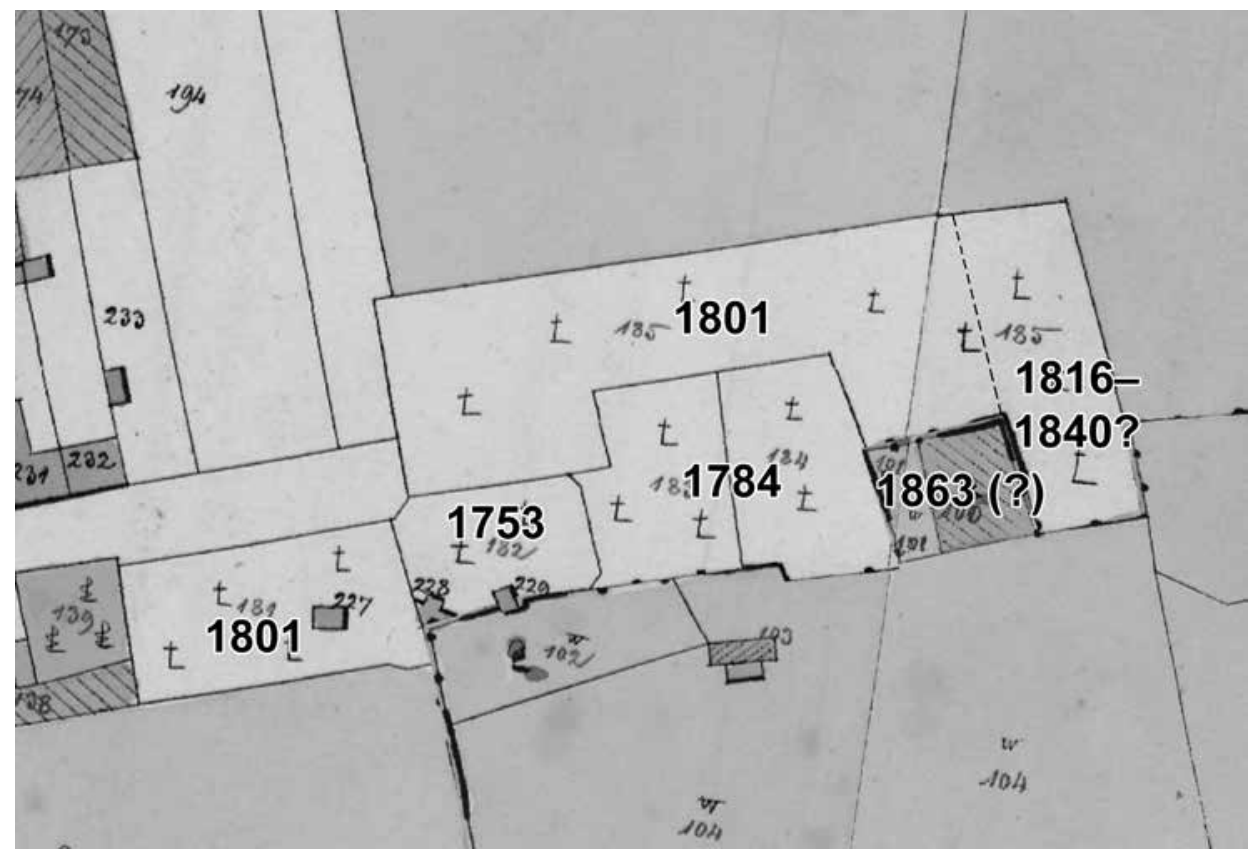

Obr. 23. Schéma rozšiřování souboru hřbitovů na císařských povinných otiscích stabilního katastru (1840-1842). Podklad http://mpp.praha.eu/OrtofotoArchiv.

Abb. 23. Erweiterungsschema des Friedhofskomplexes auf kaiserlichen verbindlichen Abdrücken des stabilen Katasters (1840-1842). Unterlage http://mpp.praha.eu/OrtofotoArchiv.

odhalil tři kostrové hroby (ADČ, BZO99 [512]). Další dokumentovaný zásah vyvolalo kopání kanalizační přípojky v prostřední části Korybutovy ulice $\mathrm{v}$ její východní polovině v roce 2015. L. Rytíř (Archeo Pro o.p.s.) zde zachytil čtyři kostrové pohřby, pozůstatek pátého (jen rakve) a ostatky dalšího jedince (Rytíř ed. 2015). Při dalších zásazích do země v okolí nové budovy lze tedy očekávat nové nálezy.

\section{Prameny}

ADČ: Archeologická databáze Čech, Archiv 3.1, verze 2010, Archeologický ústav AV ČR, Praha, v. v. i.

J. J. Clauser, Anmerckungen und Quaestiones, wie auch die hierüber versuchte Beantworttung in Angelegenheit des Pragerischen Reviers oder Forsts, Strahovská knihovna, sign. DF II 10.

KACL, P., ed., 2013: Nálezová zpráva ze zjištovacího archeologického výzkumu provedeného při akci „AFI KARLÍN BUSINESS CENTRE“. Č́slo akce Archeo Pro: 11/13 AP. Nepublikovaná nálezová zpráva ulož. v archivu Archeo Pro o.p.s.

KACL, P., ed., 2017: Nálezová zpráva ze záchranného archeologického výzkumu provedeného při akci „AFI Karlín Business Centre“. Číslo akce Archeo Pro: 35/13 AP. Nepublikovaná nálezová zpráva ulož. $\mathrm{v}$ archivu Archeo Pro o.p.s.

PAŘEZ, J., 2017: Historie naleziště. In: Nálezová zpráva ze záchranného archeologického výzkumu provedeného při akci „AFI Karlín Business Centre“. Č́slo akce Archeo Pro: 35/13 AP (Kacl, P., ed.). Nepublikovaná nálezová zpráva ulož. v archivu Archeo Pro o.p.s.

RYTÍŘ, L., ed., 2015: Nálezová zpráva ze zjištovacího archeologického výzkumu provedeného př̀ akci „Polyfunkční budova Karlín“. Č́slo akce Archeo Pro: 35/15 AP. Nepublikovaná nálezová zpráva ulož. v archivu Archeo Pro o.p.s. 
ŠULÁKOVÁ, H., 2017: Karlínský hřbitov: výsledky entomologické analýzy. In: Nálezová zpráva ze záchranného archeologického výzkumu provedeného při akci „AFI Karlín Business Centre“. Číslo akce Archeo Pro: 35/13 AP (Kacl, P., ed.). Nepublikovaná nálezová zpráva ulož. v archivu Archeo Pro o. p.s.

ZAVŘEL, J., 2017: Praha 8 - Karlín, staveniště administrativní budovy v ul. Pernerova - Korybutova. Geologické poměry archeologické lokality a petrografický rozbor vybraných nálezů. In: Nálezová zpráva ze záchranného archeologického výzkumu provedeného při akci „AFI Karlín Business Centre“. Číslo akce Archeo Pro: 35/13 AP (Kacl, P., ed.). Nepublikovaná nálezová zpráva ulož.v archivu Archeo Pro o.p.s.

\section{Literatura}

ARIÈS, P., 2000: Dějiny smrti 1. Doba ležících. Praha.

BIANUCCI, R. et al., 2009: Plague immunodetection in remains of religious exhumed from burial sites in central France, Journal of Archaeological Science 36, 616-621.

BRUZEK, J., 2002: A method for visual determination of sex, using the human hip bone, American Journal of Physical Anthropology 117, 157-168. DOI: https://doi.org/10.1002/ajpa.10012

BUIKSTRA, J. E.-UBELAKER, D. H., edd., 1994: Standards for Data Collection from Human Skeletal Remains. Fayetteville.

CASTEX, D., 2008: Identification and interpretation of historical cemeteries linked to epidemics. In: Paleomicrobiology: Past human infection (Raoult, D.-Drancourt, M., edd.), 23-48. Berlin - Heidelberg.

CASTEX, D.-GEORGES, P.-BLANCHARD, P., 2008: Complémentarité et discordances entre sources textuelles et sources archéo-anthropologiques en contexte de crises de mortalité par épidémie. Études de cas, Revue archéologique du Centre de la France 47, 1-22.

ČECHURA, M., 2012: Zaniklé kostely Čech. Praha.

DUDAY, H., 2005: L’Archéothanatologie ou l'archéologie de la mort. In: Objets et Méthodes en Paléoanthropologie (Dutour, O.-Hublin, J.-J.-Vandermeersch, B., edd.), 153-207. Paris.

- 2009: The archeology of the dead. Lectures in archaeothanatology. Oxford.

DUDAY, H. et al., 1990: Duday, H.-Courtaud, P.-Crubezy, É.-Sellier, P.-Tillier, A.-M., L’Anthropologie „de terrain“: reconnaissance et interprétation des gestes funéraires. In: Anthropologie et Archéologie Dialogue sur les Ensembles Funéraires, Bulletins et Mémoires de la Société d'Anthropologie de Paris, Numéro spécial, Tome 2 (Crubézy, É.-Duday, H.-Sellier, P.-Tillier, A.-M., edd.), 29-50.

FEREMBACH, D. et al., 1980: Ferembach, D.-Schwidetzky, I.-Stloukal, M., Recommendatios for age and sex diagnoses of skeletons, Journal of Human Evolution 9, 517-549. DOI: https://doi.org/10.1016/ 0047-2484(80)90061-5

GALETA, P. et al., 2015: Galeta, P.-Šneberger, J.-Friedl, L.-Pankowská, A.-Jurman, K.-Kubátová, I., Katalog kosterního souboru ze hřbitova u kostela sv. Máří Magdalény v Plzni. Katedra antropologie Filozofické fakulty Západočeské univerzity v Plzni. Plzeň.

GEISELBERGER, S., 2003: Pressglas aus den Glaswerken von S. Reich \& Co., Krásno, Pressglas-Korrespondenz 2003-2. Dostupné z: http://www.pressglas-korrespondenz.de/aktuelles/pdf/ geisel-glasfabrik-reich-krasno.pdf.

HEŘMÁNEK, P., 2015: „Aby nemuseli nakonec žebrati“. Př́iběhy z dějin karlínské Invalidovny. Traumata války. Sv. 3. Praha.

HUTCHINSON, D. L.-MITCHEM, J. M., 2001: Correlates of contact: epidemic disease in archaeological context, Historical Archaeology 35 (2), 58-72. DOI: https://doi.org/10.1007/BF03374384

KACL, P.-PRŮCHOVÁ, E.-RYTÍŘ́, L., 2014: Lidé mezi hroby. O výzkumu zaniklého novověkého hřbitova v Praze-Karlíně - People among graves. On the research of deserted modern era cemetery in Prague-Karlín. In: Veřejná archeologie 5 (Bureš, M.-Šmejda, L.-Šmolíková, M., edd.), 92-97. Plzeň.

KNEIDL, F., 1923: Dějiny Karlína I. Špitálsko za branou poříčskou od dávných časů až do založení Karlína. Praha.

KOSTKA, M.-ŠMOLÍKOVÁ, M., 1998: Archeologický výzkum hřbitova u kostela sv. Klimenta v Praze-Bubnech. O pohřebním ritu 19. století - Archaeological excavations in the cemetery at the Church of St Clement in Prague-Bubny; on 19th century burial rites, AR L, 822-836.

KOVAŘÍK, P., 2001: Klíč k pražským hřbitovům. Praha.

KUČERA, P., 2004: Kaple vojenského hřbitova v Karlíně aneb znovuzrození kulturní památky, Věstník Klubu Za starou Prahu 3/2004, 23-24. Dostupné z: http://stary-web.zastarouprahu.cz/ruzne/karlinkaple. htm. 
KUCHǍ̌, M., 2006: Antropologická analýza kosterního materiálu ze hřbitova okolo kostela sv. Mikuláše v Českých Budějovicích. Nepublikovaná diplomová práce, Ústav archeologie a muzeologie Filozofické fakulty Masarykovy univerzity, Brno.

LEONHARDT, R., 1905: Preussischer Krieger- und Grabdenkmäler aus den Jahren 1757, 1813 und 1866. Prag.

MARESH, M. M., 1970: Measurements from roentgenograms. In: Human growth and development (McCammnon, R. W., ed.). Springfield IL, 157-200. Citováno podle: Sheuer, L.-Black, S., 2000: Developmental juvenile osteology. New York.

MICHÁLKOVÁ, I.-MICHÁLEK, L., 2008: Zaniklé pražské vojenské hřbitovy. Praha.

MÍKA, Z., 2011: Karlín - nejstarší předměstí Prahy - Karlín - Prague’s Oldest Suburb. Praha.

NAVRÁTILOVÁ, A., 2004: Narození a smrt v české lidové kultuře - Geburt und Tod in der tschechischen Volkskultur. Praha.

OMELKA, M.-ŠLANCAROVÁ, V., 2013: Nálezy šperků, devocionálií a součástí oděvů z kostela svatého Jakuba v Jihlavě - Findings of jewellery, devotional findings and dress accessories from the Church of James the Greater in Jihlava, AVV 3, 75-132.

PAŘEZ, J., 1999: Krajina a sídla na třech mapách z historických fondů Strahovského kláštera - Landscape and Settlements on Three Maps from Historical Collections of the Premonstratensian Monastery at Strahov. In: Z pomocných věd historických XIV. Sborník k 70. narozeninám doc. PhDr. Jaroslava Kašpara, CSc. Acta universitatis Carolinae - Philosophica et historica 5 (Hlaváček, I.-Ebelová, I., edd.), 185-192. Praha.

PRŮCHOVÁ, E.-CHROUSTOVSKÝ, L.-KACL, P., v tisku: Maximizing skeletal data collection in commercial archaeology. International Journal of Osteoarchaeology. DOI: 10.1002/oa.2573 (http://onlinelibrary.wiley.com/doi/10.1002/oa.2573/full). DOI: https://oi.org/10.1002/oa.2573

RIGEADE, C., 2007: Les sépultures de catastrophe. Approche anthropologique des sites d'inhumations en relation avec des épidémies de peste, des massacre de population et des charniers militaires. BAR International Series 1695. Oxford.

SEMOTANOVÁ, E. a kolektiv, 2016: Ottův historický atlas. Praha. Krajina města. Praha.

SIGNOLI, M. et al., 2004: Discovery of mass grave of Napoleonic period in Lithuania (1812, Vilnius), C. R. Palevol 3, 219-227. DOI: https://doi.org/10.1016/j.crpv.2004.02.003

STLOUKAL, M., 1999: Paleodemografie. In: Stloukal, M. (vedoucí autorské skupiny), Antropologie. Příručka pro studium kostry, 359-373. Praha.

UBELAKER, D. H., 1989: Human Skeletal Remains. Second Edition. Washington D.C.

VÍŠKOVÁ, M., 2011: Antropologická analýza kosterního materiálu ze hřbitova okolo chrámu sv. Ducha v Hradci Králové. Nepublikovaná diplomová práce, Ústav archeologie a muzeologie Filozofické fakulty Masarykovy univerzity, Brno.

ZŮBEK, A., 2013: Hřbitov při kostele sv. Jakuba v Brně. Vyhodnocení archeologických poznatků. Nepublikovaná disertační práce, Ústav archeologie a muzeologie Filozofické fakulty Masarykovy univerzity, Brno.

\section{Internetové zdroje}

Císařské povinné otisky stabilního katastru, 1840-1842 (Praha). Archivní mapy - prezentace Ústředního archivu zeměměřictví a katastru. Dostupné z: http://archivnimapy.cuzk.cz. Uloženo v Národním archivu, fond IS, sign. Rak 67.

Monumentální plán královského hlavního města Prahy (i s nejnovější VII. částí mezi Holešovicemi a Bubny), Karlína, Král. Vinohradů, Žižkova, Bubenče, Nuslí a Smíchova, 1885, J. Brož, Virtuální mapová sbírka. Dostupné z: http://www.chartae-antiquae.cz/. Uloženo v Městské knihovně v Praze.

Ortofotomapa z leteckých snímků Prahy, 2014. Mapové aplikace Geoportálu hlavního města Prahy Institutu plánování a rozvoje hlavního města Prahy. Dostupné z: http://mpp.praha.eu/OrtofotoArchiv/.

Topografická mapa ČÚZK, Národní geoportál INSPIRE, CENIA, česká informační agentura životního prostředí. Dostupné z: http://geoportal.gov.cz/web/guest/map. 


\section{Zusammenfassung}

\section{Ein Komplex verschwundener Friedhöfe im Prager Stadtviertel Karolinenthal}

Im Bereich zwischen den Straßen Korybutova und Pernerova im Prager Stadtviertel Karolinenthal (Karlín) erfolgte eine Grabung, bei welcher die Situation eines Friedhofs erfasst wurde, der im Jahr 1753 für die Invaliden aus dem nahegelegenen Invalidenheim und bald darauf auch für die Prager Militärgarnison angelegt worden war (später erweitert). Im Jahr 1784 wurden zwei evangelische Friedhöfe angelegt, ein helvetischer und ein lutherischer. Zur Einebnung der Friedhöfe kam es im Jahr 1894. Nach den Exhumierungen wurde der Friedhof aufgeschüttet und die Grundstücke wurden über einen kurzen Zeitraum für einen allgemeinen Experimentier- und Vorratsgarten und schließlich für die Fabrikhallen von Maschinenbaufabriken genutzt.

Bei der Grabung wurden 1019 Gräber freigelegt und 1429 menschliche Skelette und ihre Teile gehoben. Vereinzelt vorkommende Knochen in Sekundärlagen wurden keine dokumentiert. Außer Einzelbestattungen wurden auch Mehrfachbestattungen mit zwei bis zu 140 Verstorbenen freigelegt. Die Massengräber unterschieden sich sowohl in der Größe der Gruben, als auch in der mehr oder weniger pietätvollen Beisetzung der Leiber. Mindestens zwei Massengräber können anhand von Münzfunden in die Zeit der napoleonischen Kriege datiert werden.

In den meisten Gräbern wurden allerdings einzelne Individuen beigesetzt, in der Regel in Holzsärgen. Diese waren in einigen Fällen mit Zierelementen aus Metall von entweder religiösem (Kreuze, Kelche) oder ornamentalem Charakter versehen. Einige Särge waren mit Metallgriffen und Beinen ausgestattet. Freigelegt wurden auch einige Särge aus Blech, offenbar Zinksärge.

In 13 Fällen fand man Amputationen von Extremitäten vor, es gab 77 Belege für Schädelobduktionen, bei denen die Schädeldecke abgetrennt und viermal eine Trepanation durchgeführt wurde.

Von den Grabausstattungen stammt eine Kollektion Begräbniskruzifixe und Hängekreuze aus verschiedenen Materialien (Metall, Bein, Holz, Perlmutt, Keramik, Gips). Entdeckt wurden einige Rosenkränze bzw. Gebetsschnüre oder deren Teile (für gewöhnlich aus Holz, Bein oder Metall), Medaillonanhänger, Glasperlen von Stirnreifen oder Kopfbedeckungen, Ringe, Ohrringe und einige weitere Funde. Ferner fand man Bekleidungsteile (Knöpfe, Haken und Ösen und Stecknadeln) und manchmal auch Reste einer Textilie selbst (von Anzügen und Kleidern). Der Erhaltungszustand der Reliquien und Artefakte wies beträchtliche Unterschiede auf.

In Sekundärlagen kamen manchmal Bruchstücke von Sandsteingrabsteinen vor. Es handelte sich entweder um die Verfüllung von Gruften, Aufschüttungen oder um Baumaterial für die Fundamente von Sockeln. In zwei Fällen sind sie mit einer Jahreszahl versehen, und zwar mit den Jahren 1769 und 1810. Dokumentiert wurden auch Baukonstruktionen, und zwar die Wände, welche die evangelischen Friedhöfe von dem Militärfriedhof sowie voneinander selbst abtrennten, verschiedene Sockelfundamente unter Denkmälern oder Grabsteinen und eingetiefte Teile von Ziegelsteingruften und Grabeinfassungen. Von zwei Dutzend Gruften wurden lediglich in drei Bestattungen erfasst und in einer die Reste von Särgen mit sekundär beigesetzten Knochen. Die meisten der Bestatteten wurden nach Auflösung des Friedhofs aus den Gruften gehoben und woanders wieder begraben. Weitere dokumentierte Konstruktionen war ein tiefgegründetes Fundamentmauerwerk und ein Keller und Brunnen mit einem Mantel aus Ziegelsteinen. Diese Bauten gehören zur Entwicklung nach dem Jahr 1906.

Mgr. Pavel Kacl, Archeo Pro, o.p. s., Zlatnická 11, 11000 Praha 1, Česká republika, pavel.kacl@archeo4u.cz

Mgr. Erika Průchová, Katedra antropologie a genetiky člověka Přírodovědecké fakulty Univerzity Karlovy, Viničná 7, 12843 Praha 2, Česká republika, erpruchova@gmail.com 
